\title{
Institutional Ownership and Return Predictability Across Economically Unrelated Stocks
}

\author{
George P. Gao, Pamela C. Moulton, and David T. Ng* \\ August 1, 2016 \\ Journal of Financial Intermediation, forthcoming
}

\begin{abstract}
We document strong weekly lead-lag return predictability across stocks from different industries with no customer-supplier linkages (economically unrelated stocks). Between 1980 and 2010, the industry-neutral long-short hedge portfolio earns an average of over 19 basis points per week. This predictability is related to common institutional ownership and is distinct from previously documented lead-lag effects. Common institutional ownership is a complementary rather than a substitute explanation for return predictability. Information linkages are enough to induce return predictability among stocks in the same industry, but economically unrelated stocks exhibit return predictability only when they have common institutional owners. Our findings suggest that institutional portfolio reallocations can induce return predictability among otherwise unrelated stocks.
\end{abstract}

* Gao is at T. Rowe Price (phone: 410-345-2517; email: george.gao@troweprice.com); Moulton is at the School of Hotel Administration, Cornell College of Business, Cornell University (phone: 607-255-9882; email: pmoulton@cornell.edu); and Ng is at the Dyson School of Applied Economics and Management, Cornell College of Business, Cornell University (phone: 607-255-0145; email: dtn4@cornell.edu). We thank an anonymous referee, Jeff Bacidore, Warren Bailey, Charlie Calomiris and Murillo Campello (the editors), Paul Gao, Byoung-Hyoun Hwang, Kewei Hou, Danling Jiang, Andrew Karolyi, Eric Kelley, Charles Lee, David Musto, Lilian Ng, Gideon Saar, Zheng Sun, Huacheng Zhang, and seminar participants at the City University of Hong Kong, Cornell Finance Brown Bag Workshop, Syracuse University, University of Wisconsin at Milwaukee, the Conference on Financial Economics and Accounting, the Mid-Atlantic Research Conference in Finance, and the Midwest Finance Association Annual Meeting for helpful comments. All opinions and inferences are attributable to the authors and do not represent the views of the T. Rowe Price Associates, Inc. 


\title{
Institutional Ownership and Return Predictability Across Economically Unrelated Stocks
}

\begin{abstract}
We document strong weekly lead-lag return predictability across stocks from different industries with no customer-supplier linkages (economically unrelated stocks). Between 1980 and 2010, the industry-neutral long-short hedge portfolio earns an average of over 19 basis points per week. This predictability is related to common institutional ownership and is distinct from previously documented lead-lag effects. Common institutional ownership is a complementary rather than a substitute explanation for return predictability. Information linkages are enough to induce return predictability among stocks in the same industry, but economically unrelated stocks exhibit return predictability only when they have common institutional owners. Our findings suggest that institutional portfolio reallocations can induce return predictability among otherwise unrelated stocks.
\end{abstract}

Keywords: Return predictability; anomalies; institutional ownership; institutional trading

JEL Classifications: G12; G14 
The finance literature has documented that some stocks lead other stocks in returns (leadlag cross-autocorrelation) in several different contexts, including from large to small firms within the same industry, between customer-supplier linked firms and industries, from more actively to less actively traded stocks, from high to low institutional ownership stocks, and from easy-toanalyze firms to complicated firms. ${ }^{1}$ In all of these cases, the explanation for the lead-lag effect is slow information diffusion, often among economically linked firms and industries. ${ }^{2}$

This paper documents a new type of return predictability that is distinct from previous studies. We investigate whether common institutional ownership (that is, the same institution holding multiple stocks) is related to return predictability between the stocks of otherwise economically unrelated firms. ${ }^{3}$ More specifically, can the historical return relations between economically unrelated stocks that have common institutional owners be used to predict the subsequent returns of a stock?

Our central idea is that after observing abnormal returns for one stock in his portfolio, an institutional investor is likely to revisit his investment decisions and re-optimize his entire portfolio, which can cause him to buy or sell stocks that are unrelated to the stock whose returns motivate the portfolio changes. For example, some institutional investors have limits on how much of their portfolios can be invested in a single stock, requiring them to sell a stock whose value rises above a certain level and reallocate the funds to other stocks in their portfolios. ${ }^{4}$ Previous theoretical and

\footnotetext{
${ }^{1}$ These phenomena are documented in Cen, Chan, Dasgupta, and Gao (2013), Hou (2007), Lo and MacKinlay (1990), Cohen and Frazzini (2008), Huang and Kale (2013), Menzly and Ozbas (2010), Chordia and Swaminathan (2000), Badrinath, Kale, and Noe (1995), and Cohen and Lou (2012), respectively.

${ }^{2}$ Other examples of lead-lag effects caused by slow information diffusion include studies showing return predictability from high analyst coverage to low analyst coverage stocks (Brennan, Jegadeesh, and Swaminathan, 1993), from low friction stocks to high friction stocks (Hou and Moskowitz, 2005), from illiquid large stocks to smaller stocks (Chordia, Sarkar, and Subrahmanyam, 2011), from globally accessible stocks to inaccessible stocks (Bae, Ozoguz, Tan, and Wirjanto, 2012), and from industries to the market (Hong, Torous, and Valkanov, 2007).

${ }^{3}$ Since all firms are exposed to market shocks and macroeconomic factors such as GDP growth and inflation, they are all economically related in the broadest sense. Our definition of "economically unrelated" specifically focuses on links between firms' cash flows that could lead to information transfers between stocks, rather than common macroeconomic fundamentals that drive all stocks' returns.

${ }^{4}$ In a related vein, Covrig, Fontaine, Jimenez-Garces, and Seasholes (2009) and Hau and Rey (2009) examine the portfolio rebalancing effect of institutions. Another example of how price changes in some stocks may
} 
empirical work finds that institutional portfolio readjustments can lead to higher return correlations among the stocks held by an institution (see, e.g., Basak and Pavlova, 2013; Cont and Wagalath, 2016; and Anton and Polk, 2012). When capital is slow moving (Duffie, 2010) or readjustments take place periodically (e.g., weekly) rather than instantaneously, the collective actions of institutional investors can give rise to price pressures and subsequent short-term return predictability (see Section 1 for discussion of related literature). ${ }^{5}$ We exclude economically linked firms from our main analysis in order to shut down the classic cash flow links between firms, allowing a clearer focus on the role of common institutional ownership. We also compare the return predictability from economically unrelated stocks to the return predictability among firms in the same industry, to examine whether institutional portfolio adjustments are a substitute or complementary explanation for return predictability among firms with clear information linkages.

Our empirical design begins with identifying pairs of stocks that are from different industries and whose industries have no supplier-customer links ("unrelated stocks"). Following Menzly and Ozbas (2010) and Huang and Kale (2013), we identify supplier-customer links from the Bureau of Economic Analysis Benchmark Input-Output Surveys. To verify that the stocks in each pair are not economically related, we also examine the correlation between their earnings surprises. The economically unrelated stock pairs have low earnings surprise correlations in general (average 0.017), and our results are robust to excluding stock pairs with significant earnings surprise correlations.

For each pair of unrelated stocks, we examine the history of how one stock's cumulative abnormal return relates to the second, economically unrelated stock's cumulative abnormal return

induce institutional trading in other stocks is provided by Hau and Lai (2016), who find evidence consistent with mutual funds that have high exposure to financial stocks engaging in asset fire sales of non-financial stocks during the 2007 financial crisis. Similarly, Broner, Gelos, and Reinhart (2006) document how fund trading can propagate financial crises.

${ }^{5}$ Chakrabarty, Moulton, and Trzcinka's (2016) model shows that rationally optimizing portfolio managers weigh the cost of readjustment (including price pressures) against the cost of being away from their desired portfolio allocations. Thus the mere existence of price pressures does not necessarily keep institutional investors from trading. 
over a subsequent week. ${ }^{6}$ We use cumulative abnormal returns rather than raw returns in order to remove market-wide effects. We apply the coefficient estimates from a historical regression to the first stock's recent performance, in order to predict the second stock's future weekly cumulative abnormal return. We then aggregate multiple return predictions (based on different economically unrelated stocks) for each stock and sort the stocks into industry-neutral portfolios based on their average predicted returns. ${ }^{7}$

We find strong weekly return predictability from economically unrelated stocks. During the 1980 to 2010 sample period, the industry-neutral long-short hedge portfolio, which is long (short) the stocks with the highest (lowest) predicted returns, earns an average of over 19 basis points per week (with a $t$-statistic above five), implying an annualized average return of nearly $10 \%$. This return predictability arises exclusively from the pairs of stocks in which there are common institutional owners. When we forecast returns using only pairs of unrelated stocks that do not share common institutional owners, we find insignificant return predictability.

A natural question is whether common institutional ownership also explains return predictability among stocks in the same industry, which should have many information linkages (unlike our main sample). We find a similar magnitude of return predictability for pairs of stocks in the same industry, but the predictability emerges both with and without common institutional owners. We conclude that common institutional ownership is a complementary rather than a substitute explanation for return predictability: Information linkages are enough to induce return predictability among stocks in the same industry, but economically unrelated stocks exhibit return predictability only when they have common institutional owners.

\footnotetext{
${ }^{6}$ For brevity, we often refer to cumulative abnormal returns as simply "returns"; all of our analyses are based on cumulative abnormal returns, as defined in Appendix A. Details of the return prediction methodology are contained in Section 2.4.

${ }^{7}$ Note that this is not a pairs trading strategy, although pairs of economically unrelated stocks are used to predict returns.
} 
To further investigate the link between institutional portfolio adjustments and return predictability among economically unrelated stocks, we examine specific times of the year when large numbers of portfolio managers are known to readjust their portfolios: the last week of June (when the Russell indexes are reconstituted), the last week of each quarter, and the last week of each month. We find that return predictability among economically unrelated stocks is significantly higher in these weeks, consistent with higher predictability being driven by more intense institutional portfolio readjustments. The return predictability also remains significant during the other weeks of the year, suggesting that it is not entirely attributable to these seasonal effects. Finally, we analyze changes in quarterly institutional holdings to investigate the mechanism through which common institutional ownership is associated with return predictability among economically unrelated stocks. We find that institutions accumulate more of stocks in the highest predicted-return quintile than in the lowest predicted-return quintile, linking return predictability to institutional portfolio changes.

We examine numerous alternative explanations to show that our results are distinct from previously documented return predictability. Our results are not explained by industry or suppliercustomer linkages between firms, as we exclude all such economically related stock pairs from our main analysis. Industry and sector rotation do not explain our results, since our strategy employs industry-neutral portfolios. Our findings are not explained by previously documented lead-lag relations arising from slow information diffusion, including from large to small firms, more actively traded to less actively traded stocks, high institutional ownership to low institutional ownership stocks, and high analyst coverage to low analyst coverage stocks. Our documented predictability is also distinct from well-known return anomalies including size effects, book-to-market effects, weekly and monthly return reversals, long-run reversals, price momentum, earnings momentum, liquidity effects, and trading volume effects. Our results are not due to nonsynchronous trading or seasonality. Our sample includes only stocks with share prices not less than $\$ 5$ at the end of the prior quarter, and the return predictability results are qualitatively unchanged when we use only 
stocks that trade every day in the previous 12 months. Overall, we find a novel, highly robust link between common institutional ownership and return predictability for economically unrelated stocks. The magnitude of the predictability, at 19 basis points per week, and the fact that it is not concentrated in small or illiquid stocks suggest that the strategy may yield a modest trading profit after transaction costs. Frazzini, Israel, and Moskowitz (2014) estimate a market impact cost of about 9 basis points for NYSE stocks and about 12 basis points for NASDAQ stocks.

The remainder of the paper is organized as follows. Section 1 describes related literature on institutional investors and stock returns. Section 2 presents the data and our methodology for constructing return predictions and forming portfolios. Section 3 presents the main results on return predictability among economically unrelated stocks with and without common institutional owners and contrasts these findings with those for stocks in the same industry. Section 4 examines how the predictability relates to seasonal patterns of institutional portfolio rebalancing and changes in institutional holdings. Section 5 investigates other possible explanations for return predictability in economically unrelated stock pairs. Section 6 discusses additional analyses and robustness checks, and Section 7 concludes. Appendix A contains variable definitions. Appendix B provides an example of how return predictions are determined using a specific pair of unrelated stocks.

\section{Relation to literature on institutional investors and stock returns}

Our paper builds on and contributes to recent literature on how institutional ownership may affect stock return variance or correlations. Greenwood and Thesmar (2011) show that "fragile" stocks (i.e., stocks with high percentages held by a few institutions) have high volatility. Anton and Polk (2012) show that the degree of common institutional ownership forecasts cross-sectional variation in return correlation, and Bartram, Griffin, Lim, and $\mathrm{Ng}$ (2013) show that foreign ownership linkage is an important driver of the covariation of returns for stocks in different countries. These studies suggest that simply by investing in multiple stocks, institutional investors 
may affect the contemporaneous return correlations between stocks. ${ }^{8}$ In addition, capital can be slow moving as Duffie (2010) suggests. Institutions may re-adjust their portfolios periodically (for example, weekly) rather than instantaneously. In this case, common institutional ownership could affect not only contemporaneous return correlations but also cross-autocorrelations of stocks they hold. Our study focuses on the unexamined question of whether common institutional investment is associated with lead-lag return predictability across different stocks. By examining the return predictability of economically unrelated stocks owned by the same institution, our study focuses on common institutional ownership in the absence of information links between firms.

Our paper is also related to, but distinct from, recent papers that emphasize fund flows as a mechanism that creates price pressure. Coval and Stafford (2007) find that funds experiencing large outflows create price pressures on stocks held in common by distressed funds. Frazzini and Lamont (2008) find that mutual fund flows negatively predict future long-term returns, and Lou (2012) finds that the mutual fund flow-driven return effect can partially explain stock price momentum. While these papers focus on how capital inflows and outflows induce trading that in turn affects stock prices, our paper investigates a different mechanism: the reallocation of institutional investors' capital from some stocks to others, which occurs whenever institutional investors adjust their portfolios, not only when large inflows or outflows occur.

This work contributes to our understanding of how institutional trading may affect returns. Previous empirical papers have documented that mutual fund herding may move the price of small stocks in subsequent quarters (Wermers, 1999; Sias, 2004). There are generally three explanations offered for why institutional trading may affect subsequent stock returns (Sias, Starks, and Titman, 2006). One is that institutions uncover private information about individual stocks and reveal it through their trading, leading to permanent price effects (e.g., Easley and O'Hara, 1987; Boehmer and Kelley, 2009). A second explanation for a permanent price effect from institutional trades is

\footnotetext{
${ }^{8}$ Similarly, the accounting literature documents evidence of institutional ownership affecting stock returns around earnings announcements (e.g., Potter, 1992; Bartov, Radhakrishnan, and Krinsky, 2000).
} 
that investors view stocks as imperfect substitutes and their long-term supply and demand curves are not perfectly elastic. Thus the traders who are on the other side of aggregate institutional trades demand lower (higher) prices to buy (sell) stocks (e.g., Shleifer, 1986; Lynch and Mendenhall, 1997). The third explanation is a temporary price effect from institutional trading. Institutional trading may affect stock prices if it pushes liquidity providers away from their preferred inventory position (e.g., Stoll, 1978; Grossman and Miller, 1988) or if there is slow movement of investment capital to trading opportunities (Duffie, 2010). We find that the return predictability from economically unrelated stocks is a temporary price effect, yielding the highest return in the first week after portfolio formation and then reversing in the following weeks. This pattern suggests that the return predictability arises primarily because aggregate trading from institutional portfolio adjustments results in temporary price pressures, rather than because institutions are trading on superior information or long-term supply and demand curves for non-institutional traders are elastic.

\section{Data and methodology}

Our analysis uses stock return data from the Center for Research in Security Prices (CRSP), earnings announcement and accounting data from Compustat, analyst forecast data from the Institutional Brokers' Estimate System (I/B/E/S) from Thomson Reuters, 13F institutional holdings data from Thomson Reuters, and information on customer-supplier industry links from the Bureau of Economic Analysis (BEA) Benchmark Input-Output Surveys. ${ }^{9}$ Our sample period is January 1980 to December 2010; we start our sample in 1980 because that is when the institutional holdings data begin. We begin with the universe of all common stocks (CRSP share codes 10 and 11) listed on NYSE, AMEX, and NASDAQ, and apply the following screens to create our sample of weekly observations: the share price at the end of the previous quarter must be greater than or equal to $\$ 5$;

\footnotetext{
${ }^{9}$ The BEA data are publicly available at http://www.bea.gov/industry/index.htm. In using the BEA data we follow Menzly and Ozbas (2010), who point out that the BEA surveys provide a more complete picture in identifying economically related stocks than the Compustat customer information database used in Menzly and Ozbas (2006) and Cohen and Frazzini (2008).
} 
the firm must be present in Compustat data for at least the prior two years; and the most recent earnings announcement must be regular and on time (i.e., the firm makes four quarterly earnings announcements each year and has earnings announced during the three-month period after the end of each fiscal quarter). In Appendix A we provide a description of all variables used in our empirical analyses.

\subsection{Economically unrelated stock pairs and same industry stock pairs}

Pairs of economically unrelated stocks are the focus of this study. Each stock whose return we are interested in predicting ("target stock") is matched with multiple economically unrelated stocks ("unrelated stocks") as follows. For each target stock in our sample each week, we identify all other stocks that do not have the same Fama-French 30 industry classification. We then determine the industry code for each stock and retain only those stocks (unrelated stocks) that are from industries that show zero dollar value of inputs/outputs between them and the industry of the target stock in the most recent BEA survey. ${ }^{10}$ We thus make sure that we are considering only stock pairs that have no industry or cash flow links between them. We recognize that despite these precautions, there still could be more subtle economic relations between any two firms, so in our robustness checks we exclude any stock pairs that have significant unexpected earnings correlations over our sample period (see Section 6.2).

To provide a benchmark for comparison, we repeat our main analyses using pairs of stocks from the same industry, defined by the Fama-French 30 industry classifications. ${ }^{11}$ Once the pairs

\footnotetext{
${ }^{10}$ We use BEA's standard make and use tables at the detailed level, which identify 484, 496, 537, 542, 498, 498, 511, and 537 industries in the surveys from 1967, 1972, 1977, 1982, 1987, 1992, 1997, and 2002, respectively. The BEA survey uses Standard Industry Codes (SIC) prior to 1997 and North American Industry Classification System (NAICS) codes from 1997 on. We merge SIC and NAICS codes as in Menzly and Ozbas (2010).

${ }^{11}$ Results using pairs of economically related stocks, of which same industry pairs are a subset, yield similar inference. We present results from same industry pairs as our benchmark because they represent a stricter definition of economically linked and therefore provide the most robust contrast.
} 
of same industry stocks are identified, we analyze them using the same methodology as for economically unrelated stock pairs, described below.

\subsection{Institutional ownership}

We count the number of common institutional owners and the number of significant common institutional owners for each pair of stocks using the quarterly $13 \mathrm{~F}$ institutional holdings data. Common institutional owners are defined as the same institutional investor holding positions in both stocks as of the prior quarter-end. Because we expect that any return predictability connected to institutional trading should be stronger when institutions have larger common holdings, we further categorize common institutional ownership as "significant" if an institution holds more of each stock than the median institutional holder of that stock. For example, if the median institutional holding in stock $\mathrm{A}$ is $0.4 \%$ of shares outstanding and the median institutional holding in stock B is $0.1 \%$, we define an institution that holds more than $0.4 \%$ of stock A and more than $0.1 \%$ of stock B as a significant common owner.

For our main analyses, we identify a stock pair as having common institutional ownership if it has common institutional owners on all of the prior 20 quarter-ends, while a stock pair would have no common institutional ownership if it has no common institutional investor in any of the prior 20 quarter-ends. ${ }^{12}$ Similarly, a pair of stocks would have no significant common institutional owners if there is no significant common institutional investor in any of the past 20 quarter-ends.

\subsection{Sample descriptive statistics}

Table 1 presents descriptive statistics for the stocks in our sample. Our sample comprises 13,109 stocks. Panel A of Table 1 shows that institutions hold $41.2 \%$ of a firm's outstanding stock

\footnotetext{
${ }^{12}$ Results are robust to determining common ownership based on institutional holdings as of only the prior quarter-end, as in Anton and Polk (2012), rather than over the prior 20 quarters. We focus on the prior 20 quarters for our main analyses because our predicted returns are based on a trailing five-year regression analysis, as described in Section 2.4 below.
} 
on average, and the average firm has 93 institutional investors. Panel B provides some basic statistics about the pairs of economically unrelated stocks. On average there are 215 unrelatedstock pairs for each target stock. ${ }^{13}$ Of the average 215 economically unrelated pairs of stocks, 188 have significant common institutional investors and 206 have common institutional investors. We note the small number of economically unrelated pairs that have no significant common institutional owners (an average of 20) or no common institutional owners (an average of 10); in our robustness checks we verify that the small number of pairs in these categories does not drive our results. On average there are 10 significant common institutional investors per stock pair and 27 common institutional investors per stock pair. The prevalence and variation of institutional ownership make this a promising sample in which to examine the link between institutional ownership and return predictability.

\section{[Table 1 here]}

\subsection{Return prediction and portfolio formation methodology}

The underlying mechanism we envision is that information about a specific economically unrelated stock affects investment decisions in the target stock because the portfolio manager reoptimizes his entire portfolio, trading many stocks (including the target stock), not just the one whose price has changed. We examine return predictability at a weekly frequency to follow the lead-lag predictability literature (e.g., Lo and McKinlay, 1990; and Hou, 2007) and because conversations with institutional portfolio managers suggest that many managers readjust their portfolios on a weekly basis. Focusing on weekly intervals also alleviates microstructure concerns such as bid-ask bounce. To determine which stock in an unrelated stock pair is the target stock (whose return is being predicted) and which is the unrelated stock (whose return is used to predict

\footnotetext{
${ }^{13}$ In our robustness checks we test whether predictability is significantly affected by the number of economically unrelated pairs available.
} 
the target's return), we determine which stock has had a more recent earnings announcement. ${ }^{14}$ The stock with the most recent earnings announcement date is designated the unrelated stock and used to predict the return of the target stock.

To illustrate our return prediction methodology, consider one target stock and one unrelated stock in a particular week. We count the number of full weeks since the unrelated stock's last earnings announcement and the number of full weeks since the target stock's last earnings announcement; see Figure 1.

Figure 1: Timing for return prediction methodology

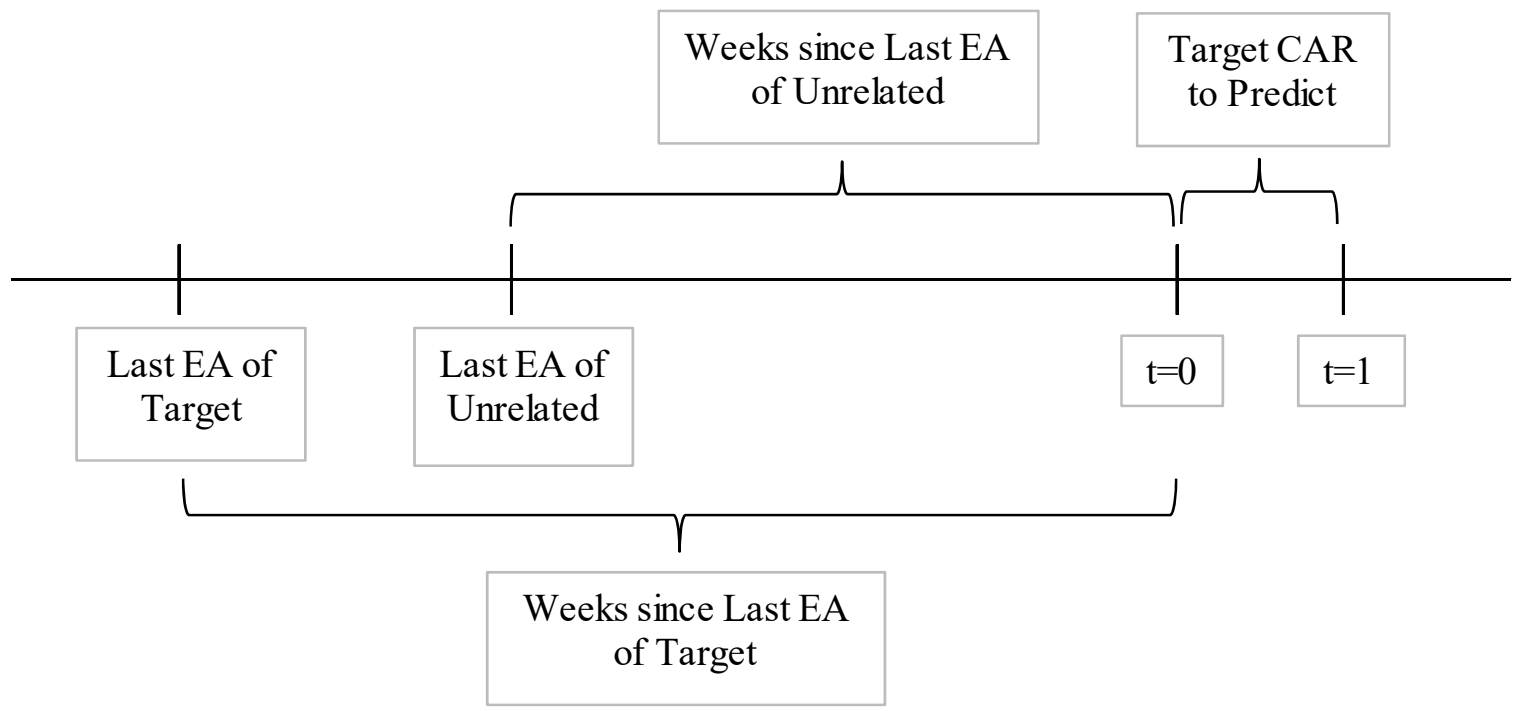

We then search the previous five years to find occasions when the unrelated stock was exactly the same number of weeks past its most recent earnings announcement and the target stock's last earnings announcement was at least one week prior to the unrelated stock's. ${ }^{15}$ For each occasion in the last five years, we calculate the unrelated stock's average cumulative abnormal

${ }^{14}$ Other information events, such as dividend payout announcements, merger and acquisition announcements, and idiosyncratic firm news, do not occur with enough regularity to facilitate broad analysis. Note that in this exercise we are not exploiting the information transfers among firms within the same industry, because we explicitly exclude stock pairs from the same or related industries.

${ }^{15}$ In using five years of earnings history we follow the literature on earnings releases and anomalies (e.g., Foster, Olsen, and Shevlin, 1984). The target stock is not allowed to have more than 12 post-earningsannouncement weeks because firms generally announce their quarterly earnings every three months. 
return $(\mathrm{CAR})$ over its post-earnings-announcement weeks until the week of interest. ${ }^{16} \mathrm{We}$ also calculate the CAR for the target stock over the subsequent week.

We regress the target stock's subsequent-week CAR on the average CAR of the unrelated stock over the previous weeks since the unrelated stock's earnings announcement. We use data from all eligible historical periods to run the regression and obtain the coefficients. We apply the coefficients from the historical regression to the average CAR for the unrelated stock over its current post-earnings-announcement weeks to predict the target stock's return for the next week. Appendix B contains a detailed example of the prediction methodology for one pair of economically unrelated stocks.

For each target stock, we calculate the predicted CAR for the next week based on each of its unrelated stocks. We calculate the target stock's average predicted CAR for the next week as the mean of the predictions from all of its unrelated stocks. ${ }^{17}$ Note that since the predicted return and the stock returns used to predict it are all cumulative abnormal returns, market-wide effects are already removed.

Finally, we form industry-neutral quintile portfolios based on the target stocks' predicted returns, to prevent our results from being driven by industry rotation. ${ }^{18}$ We repeat this procedure for all stocks each week to form weekly quintile portfolios based on predicted weekly returns.

\footnotetext{
${ }^{16} \mathrm{We}$ require at least three years of earnings announcement date history and at least 10 valid occasions to estimate the regression for a stock pair. Our choice of 10 valid occasions as a minimum (versus the maximum of 12 in three years) recognizes a natural trade-off: Requiring more valid occasions may reduce the noise in each stock-pair regression but would also reduce the number of available stock-pairs, potentially increasing the noise from the averaging across stock pairs. Since firms generally time their earnings announcements similarly across quarters and years, we typically find an adequate number of valid occasions.

${ }^{17}$ We also consider the weighted mean of the predictions from unrelated stocks where weights are based on the precisions of predicted values. The results are qualitatively similar to those based on the simple average. ${ }^{18}$ To form industry-neutral quintile portfolios, we identify all of the target stocks by their Fama-French 30 industries, and within each industry we sort the target stocks into five groups (each containing $20 \%$ of the stocks in that industry): Group 1 contains the target stocks with the lowest predicted returns for the following week, and Group 5 contains the target stocks with the highest predicted returns for the following week. We then form industry-neutral portfolios by combining the target stocks in Group 1 from all 30 of the FamaFrench industries into a single Quintile 1 portfolio, and similarly with the remaining four groups to form the five industry-neutral predicted-return portfolios.
} 
Table 2 presents descriptive statistics for the quintile portfolios, which form the basis for our tests. We calculate simple averages of firm-level characteristics for stocks within each quintile and then report time-series averages of each quintile's characteristics from January 1980 to December 2010. Panel A shows that there are variations across the predicted-return portfolios in terms of the component stocks' size, book-to-market, lagged returns, volatility, liquidity, and trading volume. For example, the predicted-CAR-sorted portfolios are monotonically decreasing in book-to-market and increasing in price momentum over the previous year (Return month t-12 to $\mathrm{t}-2)$. Therefore in addition to investigating the potential relation of return predictability to common institutional ownership, we examine other previously documented explanations for return predictability, such as size, book-to-market, momentum, reversals, and liquidity, in Section 5. Panel B shows that return autocorrelations are generally small in each of the quintile portfolios.

[Table 2 here]

\section{Return predictability and common institutional ownership}

Panel A of Table 3 presents our first results on return predictability from economically unrelated stock pairs, using all economically unrelated stock pairs to predict returns. We report the value-weighted weekly excess return (ER) and value-weighted alphas from Capital Asset Pricing Model (CAPM), Fama-French three-factor (FF3), and Fama-French-Carhart four-factor (FFC4) regressions for each portfolio (Fama and French, 1993; Carhart, 1997). ${ }^{19}$ The excess returns and alphas are reported in percent; for example, the excess return of 0.020 for Quintile 1 represents 2.0

\footnotetext{
${ }^{19}$ All results are qualitatively similar when returns are equal-weighted rather than value-weighted. We use value weights rather than equal weights in the calculation of daily portfolio returns for the following three reasons: (1) equal-weighting of daily returns leads to portfolio returns that may be overstated because of the bid-ask bounce effect (see Blume and Stambaugh, 1983; and Canina, Michaely, Thaler, and Womack, 1998); (2) equal-weighting of daily returns essentially assumes daily rebalancing of portfolios, which could further overstate the economic magnitude of the returns: and (3) value-weighting of daily returns better captures the economic significance of the covariance in implied returns because equal-weighting of returns overrepresents smaller firms. Value-weighting may bias against finding any evidence of abnormal returns, since stocks with larger market capitalization are more likely to be informationally efficient, including efficiency in the incorporation of information from the early announcers.
} 
basis points per week. Quintile 1 (5) is an industry-neutral portfolio containing stocks with the lowest (highest) predicted returns, and the bottom row tests the return difference between Quintile 5 and Quintile 1 (Q5-Q1 spread), the classic long-short portfolio. We find strong return predictability in this long-short portfolio, with weekly excess return and Fama-French-Carhart alpha both over 19 basis points and $t$-statistics of 5.3 and 5.7, respectively. ${ }^{20}$

\section{[Table 3 here]}

Panel B of Table 3 presents results on return predictability from same industry stock pairs, using all pairs of stocks from the same industry to predict returns, for comparison to the results for economically unrelated stock pairs. The return predictability for same industry stock pairs (Panel B) is the same order of magnitude as for economically unrelated stock pairs (Panel A), and the differences between the return predictability for economically unrelated and same industry stock pairs are not significant.

Our main results are presented in Table 4, where we calculate predicted returns using subsets of the stock pairs: economically unrelated stock pairs in Panels A and B and same industry stock pairs in Panels C and D. In Panel A of Table 4, we calculate predicted returns for each stock first using only economically unrelated stock pairs that have significant common institutional owners, and then using only stock pairs that have no significant common institutional owners. Panel A compares the weekly return performance of each set of predicted return quintile portfolios. Portfolios formed based on predicted returns from stocks with significant common institutional owners (the first four columns) show strong predictability: The excess return difference in the longshort portfolio is 19.8 basis points per week with a $t$-statistic of 4.8 . In contrast, portfolios formed using only predicted returns from stocks with no significant common institutional owners (the middle four columns) show insignificant return spreads in the long-short portfolio: spreads of less than five basis points per week with $t$-statistics just over one. The final four columns show that the

\footnotetext{
${ }^{20}$ Factor loadings from the four-factor Fama-French-Carhart regressions are reported in the Internet Appendix.
} 
difference between the long-short portfolio returns using stock pairs with versus without significant common institutional owners is also significant. The excess return difference is estimated at 15.5 basis points, risk-adjusted alphas are of similar magnitude, and all are significant.

Panel B of Table 4 shows that this pattern is not repeated for same industry stock pairs. The return predictability for same industry stock pairs remains strong both with and without significant common institutional owners, and the difference between those with and without significant common institutional owners is insignificant. This suggests that while the natural economic links between same industry stock pairs is enough to create return predictability (with or without significant common institutional owners), for economically unrelated stock pairs (which lack natural information linkages) the return predictability arises only when there are common institutional owners. Panels $\mathrm{C}$ and $\mathrm{D}$ find similar results using a more general definition of common institutional owners, instead of significant common institutional owners.

These results support our conjecture that return predictability among economically unrelated stocks is related to common institutional ownership.

\section{[Table 4 here]}

We extend our analysis of one-week return predictability among economically unrelated stocks with versus without significant common institutional investors by calculating the weekly Fama-French-Carhart 4-factor alpha for each portfolio and the long-short portfolio strategy from one week to twelve weeks after portfolio formation. Figure 2 shows that the first-week alpha is much higher for the long-short strategy based on stock pairs with significant common institutional investors, as in Table 4, Panel A. The abnormal returns dissipate quickly and are reversed in the following weeks, leading to cumulative average weekly returns near zero for the longer holding periods, consistent with institutional investors' trading patterns creating temporary price pressures (e.g., Stoll, 1978; Grossman and Miller, 1988; Duffie, 2010). The timing of the reversals over the following several weeks is consistent with that of other reversals documented in the literature (e.g., Cohen and Lou, 2012; Coval and Stafford, 2010). 


\section{[Figure 2 here]}

\section{Return predictability and institutional portfolio rebalancing}

Prior literature suggests that institutional investors are more concerned about readjusting their portfolios at certain times of the year. For example, many managers rebalance their portfolios when the Russell stock indexes are reconstituted at the end of June; other studies find evidence consistent with portfolio rebalancing at quarter-ends and month-ends (e.g., Lakonishok, Shleifer, Thaler, and Vishny, 1991; Moulton, 2005). In our context, we thus expect to see stronger predictability arising at the end of June and at quarter- and month-ends, and a natural question is whether all of the predictability we document is driven by these particular weeks. In Panel A of Table 5 we separate out the last week of June, when Russell index reconstitutions occur; in Panels $\mathrm{B}$ and $\mathrm{C}$ we separate out the last week in each calendar quarter and each month, respectively. We find larger Quintile 5 minus Quintile 1 return differences in the Russell reconstitution, end-ofquarter, and end-of-month weeks than other weeks, although the differences between Quintile 5 and Quintile 1 remain significant in the other weeks. The higher predictability in Russell reconstitution, quarter-end, and month-end weeks is consistent with increased portfolio adjustments at those intervals.

\section{[Table 5 here]}

We next analyze institutional portfolio changes to see whether they are consistent with our notion of how common institutional ownership is related to return predictability in economically unrelated stocks. We examine the changes in quarterly institutional holdings of stocks in the high versus low predicted return quintiles. We posit that institutions increase their holdings more in stocks in the highest predicted return quintile (Quintile 5) than stocks in the lowest predicted return quintile (Quintile 1). Quintile portfolios are formed weekly, but institutional holdings are reported only quarterly, so we focus on stocks that are consistently ranked in the same quintile throughout 
the calendar quarter. Table 6 presents the change in percentage institutional ownership for stocks consistently ranked in each predicted return quintile during the same calendar quarter.

\section{[Table 6 here]}

Panel A of Table 6 presents the results for stocks that are in the same quintile portfolio for at least $75 \%$ of the weeks in the quarter; Panel B presents the results for stocks that are in the same quintile portfolio for at least $50 \%$ of the weeks in the quarter. Overall, the results show that institutional investor ownership increases more for stocks with the highest predicted returns (Quintile 5) than for those with the lowest predicted returns (Quintile 1). For example, Panel A shows that the average change in percentage institutional ownership is more than one percentage point greater for Quintile 5 than for Quintile 1 stocks, and the difference is significant. This evidence is consistent with the notion that institutional trading activity induces the return predictability among economically unrelated stocks.

\section{Alternative explanations for return predictability}

In this section we examine whether our findings on the link between common institutional ownership and return predictability are simply a manifestation of other factors that are already known to be related to return predictability.

Table 7 examines lead-lag effects. Return predictability is known to be related to the relative size of firms, with large-firm returns leading small-firm returns (e.g., Lo and MacKinlay, 1990; and Hou, 2007). Panel A shows that our predictability results are significant when predicted returns are calculated based on stock pairs in which the target firm is from a larger or equal size decile than the economically unrelated stock used to predict its return (left panel) and when the target firm is smaller (right panel). ${ }^{21}$ Cohen and Lou (2012) find that the returns of stand-alone firms, which operate in only one industry, can be used to predict the returns of conglomerates,

\footnotetext{
${ }^{21} \mathrm{Hou}$ (2007) shows that the lead-lag effect from large firms to small firms is mainly driven by intra-industry effects; since we exclude firm pairs within the same industry, our findings are not a contradiction of his.
} 
which are involved in multiple industries but are assigned a single SIC code that reflects the firm's main industry segment. To verify that our results are not driven by the presence of conglomerates, we run our analysis using stock pairs in which all of the stocks are stand-alone firms and, separately, all of the stocks are conglomerates. ${ }^{22}$ Panel B shows that our results are robust to excluding conglomerates.

Chordia and Swaminathan (2000) find a lead-lag effect from more actively traded stocks to less actively traded stocks. Panel $\mathrm{C}$ shows that our predictability results are significant when predicted returns are calculated separately based on stock pairs in which the target firm is from a larger or equal NYSE/AMEX volume decile than the economically unrelated stock (left panel) and when the target firm is from a smaller volume decile (right panel). Panel D presents analogous results using pairs of NASDAQ stocks.

Badrinath, Kale, and Noe (1995) find that stocks with high institutional ownership lead the returns of stocks with low institutional ownership. Panel E shows that our predictability results are significant when predicted returns are calculated separately based on stock pairs in which the target firm has higher or equal decile institutional ownership than the economically unrelated stock (left panel) and when the target firm has lower decile institutional ownership (right panel).

Brennan, Jegadeesh, and Swaminathan (1993) find return predictability from stocks with high analyst coverage to stocks with low analyst coverage. Panel F shows that our results are robust to using stock pairs in which the target firm has higher or equal (left panel) or lower (right panel) analyst coverage than the unrelated stock. In short, none of the previously documented lead-lag relationships explain our results.

\section{[Table 7 here]}

Another natural question is whether our results could be due to other well-documented return anomalies rather than institutional ownership per se (for example, we know from Table 2

\footnotetext{
${ }^{22}$ We thank Dong Lou for sharing his list of conglomerates and stand-alone firms.
} 
that our predicted-CAR-sorted portfolios are monotonically decreasing in book-to-market and increasing in prior-year price momentum). Table 8 reports double sorting results in which we conduct independent, industry-neutral sorts on predicted CARs and firm size, book-to-market equity, weekly return reversals, monthly return reversals, momentum, long-run return reversals, earnings momentum, liquidity, and NYSE/AMEX trading volume and turnover. Our interest in these double sorts is whether we find predictability (significant Quintile 5 minus Quintile 1 differences) within secondary sorts on each of these stock characteristics. We find that our return predictability is robust to all of these secondary portfolio sorts. In particular, our results are not driven by weekly or monthly return reversal or momentum effects. For brevity, we report only the top and bottom predictability quintiles and their differences in Table 8; full quintile results are reported in the internet appendix.

\section{[Table 8 here]}

Next we conduct Fama-MacBeth (1973) cross-sectional regressions to test whether the return predictability arising from economically unrelated stocks remains significant in a multivariate setting that includes explanatory variables previously linked to return predictability. Table 9 presents the results of the time-series average of Fama-MacBeth regression coefficients (and t-statistics) when we regress stocks' weekly excess returns on the previously predicted CARs. In particular, we use each stock's predicted-return quintile number ( $5=$ highest predicted return, $1=$ lowest) as the first explanatory variable, and we include other known explanatory factors as control variables in alternate specifications. In specifications (1) and (2), the predicted CARs are based on all economically unrelated stock pairs. The coefficient on the predicted CAR is positive and highly significant, showing that the predictability documented in this paper is not subsumed by return reversals, price momentum, earnings momentum, or other firm characteristics including market capitalization, book-to-market equity, operating accruals, net stock issuance, idiosyncratic volatility, or Amihud illiquidity.

\section{[Table 9 here]}


In specifications (3) and (4), the predicted CARs are based on only economically unrelated stock pairs with significant common institutional owners. The coefficients on predicted CAR remain positive and highly significant. In contrast, the coefficients on predicted CAR are insignificant in specifications (5) and (6), where the predicted CARs are based on pairs with no significant common institutional owners. Taken together, the results in Tables 7, 8, and 9 confirm that the return predictability is driven by stock pairs with significant common institutional owners and is not subsumed by other documented sources of predictability.

\section{Additional analyses and robustness checks}

Figure 3 graphs annual long-short portfolio returns and Sharpe ratios over the 31-year period, to show how the return predictability performs over time. The long-short hedge portfolio annual return is calculated as the average weekly excess return times the number of weeks in the year. The Sharpe ratio divides the annual excess return by the annualized standard deviation of weekly returns. The annual return is positive in all but three years of the sample period and notably remains positive even during the financial crisis in 2007-2009.

\section{[Figure 3 here]}

\subsection{Positive versus negative predicted returns}

The intuition behind our empirical set-up is that after observing the return on one stock he owns, a portfolio manager decides to buy or sell a different, economically unrelated stock. If he wants to buy, he could either buy more of a stock he already owns or buy another stock, but if he wants to sell, his choices are likely limited to stocks he already owns. Thus stocks may experience

more selling rather than buying pressures from owners who reallocate from their other portfolio holdings. Based on this intuition, we might expect the return predictability to be stronger for stocks when the signals from the economically unrelated stocks suggest selling (i.e., a negative predicted return). 
In Table 10, we predict returns separately for stocks using only the signals from economically unrelated stocks with significant common institutional investors that predict a negative return versus only signals that predict a positive return. As we are using only a subset of the available signals (positive or negative) for each stock, we expect the resulting predicted return for each stock to be noisier and the Quintile 5 minus Quintile 1 spread within each subset to be less significant.

\section{[Table 10 here]}

Panel A shows some predictability when we use only the negative signals, but we find no predictability when we use only the positive signals. Using only pairs predicting negative returns, the Quintile 5 minus Quintile 1 spread after controlling for Fama-French and Fama-French-Carhart factors is significant. In contrast, using only pairs predicting positive returns, none of the Quintile 5 minus Quintile 1 differences are significant. These subset results are consistent with our expectation that return predictability is stronger for stocks when the signals from the economically unrelated stocks suggest selling (i.e., a negative predicted return).

In Panel B we investigate the negative-predicted-return signals in more detail, bearing in mind that the more finely we separate the subsets the harder it is to see any predictability within the subset. Negative-predicted-return signals can arise in two ways. First is an unrelated-stock-loss channel. After one stock's price declines, institutional investors may sell another stock in order to reduce their equity exposure (similar to Kodres and Pritsker, 2002) or to meet liquidity demands (Coval and Stafford, 2007). In our empirical set-up, such cases arise when two stocks have a positive historical correlation and the unrelated stock has a negative recent return. Second is a return-chasing channel. After one stock's price rises, in order to increase their investment in that stock institutional investors may sell another stock (Bohn and Tesar, 1996). In our setting, this happens when two stocks have a negative historical correlation and the unrelated stock has a positive recent return. Panel B presents the results separately for the unrelated-stock-loss and return-chasing channels. We find some support for the unrelated-stock loss channel (Fama-French 
and Fama-French-Carhart Q5-Q1 spreads are significant) and less support for the return-chasing channel (only Fama-French Q5-Q1 spread is significant).

\subsection{Narrower definition of economically unrelated stocks}

Even though the stock pairs we identify have no direct cash flow links (since they are from different industries that have zero dollar value in the standard BEA make-use tables), it is possible that they could have some more subtle economic links that our methodology does not capture. To account for this possibility, we examine the correlations between unexpected earnings for each pair of economically unrelated stocks over our entire sample period. As Panel A of Table 11 shows, the average correlation is only 0.017 . About $9.5 \%$ of the stock pairs in our sample exhibit significant correlations between their unexpected earnings. In Panel B of Table 11, we exclude all stock pairs that have significant correlations between their unexpected earnings, calculate predicted returns, and repeat our quintile sorts. The Quintile 5 minus Quintile 1 return differences range from 17.2 to 20.4 basis points and remain statistically significant, suggesting that our results are not driven by some more subtle economic link between the stocks in each pair.

\section{[Table 11 here]}

\subsection{Other robustness checks}

We conduct three additional tests to confirm the robustness of our results (results tabulated in internet appendix). To verify that our predictability findings are not due to non-synchronous trading, we restrict stocks to those that have traded every day in the prior 12 months, which yields identical inference. To determine whether the predictability is driven by stocks that have the most (or fewest) economically unrelated stock pairs, we perform a double sort, with the secondary sort on the number of stock pairs used to predict the target stock's return. We find strong and significant predictability across all of the secondary sorts, showing that the predictability is not driven by stocks with the most or fewest pairs. Finally, to verify that our main results are not driven by the 
small number of economically unrelated stock pairs with no common institutional investors, we perform simulation exercises as follows. For each target firm, we count the number of stock pairs with no common institutional investors, randomly draw the same number of pairs from among the pairs with common institutional investors to predict returns, and form quintile portfolios. We run 1000 simulations, and the results show that long-short portfolio excess returns and alphas from these matched-number-of-pairs strategies remain significantly positive and are more than double the returns for the strategy based on stock pairs with no common institutional investors.

\section{Conclusion}

In this study we document a new type of lead-lag return predictability that is complementary to lead-lag effects that have been previously documented. This predictability is distinct from previously documented lead-lag effects driven by slow information diffusion, as we focus on economically unrelated stock pairs (stocks from different industries with no suppliercustomer links). We find that economically unrelated stock pairs with common institutional investors can be used to predict subsequent returns, while stock pairs without common institutional investors yield insignificant predictability. The predictability is reversed in subsequent weeks, consistent with temporary price pressures and the general pattern of institutional trading. The predictability is not explained by any previously identified factors and is consistent with optimizing behavior of institutional portfolio managers. Overall, the picture that emerges suggests that by adjusting their portfolios in systematic ways, institutional investors themselves affect stock returns and covariances and thus can induce return predictability. That said, our main interest is in documenting a new type of lead-lag return predictability, and we cannot unequivocally establish the direction of causality in our study.

Using economically unrelated stocks to predict returns allows us to focus on the role of common institutional investment, shutting down the cash flow links between firms that may lead to information spillovers affecting trading. In a complementary analysis using pairs of stocks from 
the same industry, we find equivalent return predictability overall, but the predictability occurs irrespective of common institutional ownership. In other words, for stocks with natural informational linkages, return predictability does not depend on common institutional owners; it is only for stocks without natural informational linkages that common institutional ownership drives return predictability. Practitioners, who are less interested in distinguishing between the possible roots of return predictability than in exploiting predictability, would likely include pairs of stocks from the same or related industries as well as economically unrelated stocks. Similarly, one could allow industry concentration in the portfolios to pick up possible industry or sector rotation effects, rather than constructing industry-neutral predicted return portfolios, as we do in this study. 


\section{References}

Amihud, Yakov, 2002. Illiquidity and stock returns: cross section and time-series effects. Journal of Financial Markets 5, 31-56.

Ang, Andrew, Robert J. Hodrick, Yuhang Xing, and Xiaoyan Zhang, 2006. The cross-section of volatility and expected returns, Journal of Finance 61, 259-299.

Anton, Miguel, and Christopher Polk, 2012. Connected stocks, Journal of Finance 69, 1099-1127.

Badrinath, S. G., Jayant Kale, and Thomas Noe, 1995. Of shepherds, sheep, and the crossautocorrelations in equity returns, Review of Financial Studies 8, 401-430.

Bae, Kee-Hong, Arzu Ozoguz, Hongping Tan, and Tony Wirjanto, 2012. Do foreigners facilitate information diffusion in emerging markets? Journal of Financial Economics 105, 209-227.

Bartov, Eli, Suresh Radhakrishnan, and Itzhak Krinsky, 2000. Investor sophistication and patterns in stock returns after earnings announcements, The Accounting Review 75, 43-63.

Bartram, Sohnke, John Griffin, Taehoon Lim, and David T. Ng, 2015. How important are foreign ownership linkages for international stock returns? Review of Financial Studies, forthcoming.

Basak, Suleyman, and Anna Pavlova, 2013. Asset prices and institutional investors, American Economic Review 103, 1728-1758.

Blume, Marshall, and Robert Stambaugh, 1983. Biases in computed returns: an application to the size effect, Journal of Financial Economics 12, 387-404.

Boehmer, Ekkehart, and Eric Kelley, 2009. Institutional investors and the informational efficiency of prices, Review of Financial Studies 22, 3563-3594.

Bohn, Henning, and Linda L. Tesar, 1996. U.S. equity investment in foreign markets: portfolio rebalancing or return chasing? American Economic Review: Papers and Proceedings 86, 77 81.

Brennan, Michael J., Narasimhan Jagadeesh, and Bhaskaran Swaminathan, 1993. Investment analysis and the adjustment of stock prices to common information, Review of Financial Studies 6, 799-824.

Broner, Fernando, R. Gaston Gelos, and Carmen M. Reinhart, 2006. When in peril, retrench: testing the portfolio channel of contagion, Journal of International Economics 69, 203-230.

Canina, Linda, Roni Michaely, Richard Thaler, and Kent Womack, 1998. Caveat compounder: a warning about using the daily CRSP equal-weighted index to compute long-run excess returns, Journal of Finance 53, 403-416.

Carhart, Mark, 1997. On persistence in mutual fund performance, Journal of Finance 52, 57-82. 
Cen, Ling, Kalok Chan, Sudipto Dasgupta, and Ning Gao, 2013. When the tail wags the dog: Industry leaders, limited attention, and spurious cross-industry information diffusion, Management Science 59, 2566-2585.

Chakrabarty, Bidisha, Pamela C. Moulton, and Charles Trzcinka, 2016. The performance of shortterm institutional trades, Journal of Financial and Quantitative Analysis, forthcoming.

Chan, Louis K., Narasimhan Jegadeesh, and Josef Lakonishok, 1996. Momentum strategies, Journal of Finance 51, 1681-1713.

Chordia, Tarun, Asani Sarkar, and Avanidhar Subrahmanyam, 2011. Liquidity dynamics and crossautocorrelations, Journal of Financial and Quantitative Analysis 46, 709-736.

Chordia, Tarun, and Bhaskaran Swaminathan, 2000. Trading volume and cross-autocorrelations in stock returns, Journal of Finance 55, 913-935.

Cohen, Lauren, and Andrea Frazzini, 2008. Economic links and predictable returns, Journal of Finance 63, 1977-2011.

Cohen, Lauren, and Dong Lou, 2012. Complicated firms, Journal of Financial Economics 104, 383-400.

Cont, Rama, and Lakshithe Wagalath, 2016. Institutional investors and the dependence structure of asset returns, International Journal of Theoretical and Applied Finance 19, 37 pages.

Coval, Joshua, and Erik Stafford, 2007. Asset fire sales (and purchases) in equity markets, Journal of Financial Economics 86, 479-512

Covrig, Vicentiu M., Patrice Fontaine, Sonia Jimenez-Garces, and Mark S. Seasholes, 2009. Information and cross-border equity holdings, Working paper.

Duffie, Darrell, 2010. Presidential address: asset price dynamics with slow-moving capital, Journal of Finance 65, 1237-1267.

Easley, David, and Maureen O’Hara, 1987. Price, trade size and information in securities markets, Journal of Financial Economics 19, 69-90.

Fama, Eugene, and Kenneth French, 1993. Common risk factors in the returns on stocks and bonds, Journal of Financial Economics 33, 3-56.

Fama, Eugene, and Kenneth French, 2008. Dissecting anomalies, Journal of Finance 63, 16531678.

Fama, Eugene, and James D. MacBeth, 1973. Risk, return and equilibrium: empirical tests, Journal of Political Economy 81, 607-636.

Foster, George, Chris Olsen, and Terry Shevlin, 1984. Earnings releases, anomalies, and the behavior of security returns, The Accounting Review 59, 574 -603. 
Frazzini, Andrea, Ronen Israel, and Tobias J. Moskowitz, 2014. Trading costs and asset pricing anomalies, Working paper.

Frazzini, Andrea, and Owen Lamont, 2008. Dumb money: mutual fund flows and the cross-section of stock returns, Journal of Financial Economics 88, 299-322

Greenwood, Robin, and David Thesmar, 2011. Stock price fragility, Journal of Financial Economics 102, 471-490.

Grossman, Sanford J., and Merton H. Miller, 1988. Liquidity and market structure, Journal of Finance 43, 617-633.

Hau, Harald, and Sandy Lai, 2016. The role of equity funds in the financial crisis propagation, Review of Finance, forthcoming.

Hau, Harald, and Helene Rey, 2009. Global portfolio rebalancing under the microscope, Working paper.

Hong, Harrison, Walter Torous, and Rossen Valkanov, 2007. Do industries lead stock markets? Journal of Financial Economics 83, 367-396.

Hou, Kewei, 2007. Industry information diffusion and the lead-lag effect in stock returns, Review of Financial Studies 20, 1113-1138.

Hou, Kewei, and Tobias Moskowitz, 2005. Market frictions, price delay and the cross-section of expected returns, Review of Financial Studies 18, 981-1020.

Huang, Lixin, and Jayant R. Kale, 2013. Product market linkages, manager quality, and mutual fund performance, Review of Finance, forthcoming.

Kodres, Laura E., and Matthew Pritsker, 2002. A rational expectations model of financial contagion, Journal of Finance 57, 768-99.

Lakonishok, Josef, Andrei Shleifer, Richard Thaler, and Robert Vishny, 1991. Window dressing by pension fund managers, Behavioral Finance 81, 227-231.

Lo, Andrew W., and A. Craig MacKinlay, 1990. When are contrarian profits due to stock market overreaction? Review of Financial Studies 3, 175-205.

Lou, Dong, 2012. A flow-based explanation for return predictability, Review of Financial Studies $25,3457-3489$.

Lynch, Anthony W., and Richard R. Mendenhall, 1997. New evidence on stock price effects associated with changes in the S\&P 500, Journal of Business 70, 351-384.

Menzly, Lior, and Oguzhan Ozbas, 2006. Cross-industry momentum, Working paper.

Menzly, Lior, and Oguzhan Ozbas, 2010. Market segmentation and cross-predictability of returns, Journal of Finance 65, 1555-1580. 
Moulton, Pamela C., 2005. You can't always get what you want: trade-size clustering and quantity choice in liquidity, Journal of Financial Economics 78, 89-119.

Potter, Gordon, 1992. Accounting earnings announcements, institutional investor concentration, and common stock returns, Journal of Accounting Research 30, 146-155.

Sadka, Ronnie, 2006. Momentum and post-earnings announcement drift anomalies: the role of liquidity risk, Journal of Financial Economics 80, 309-349.

Shleifer, Andrei, 1986. Do demand curves for stocks slope down? Journal of Finance 41, 579-590.

Sias, Richard W., 2004. Institutional herding, Review of Financial Studies 17, 165-206.

Sias, Richard W., Laura T. Starks, and Sheridan Titman, 2006. Changes in institutional ownership and stock returns: assessment and methodology, Journal of Business 79, 2869-2910.

Sloan, Richard G., 1996. Do stock prices fully reflect information in accruals and cash flows about future earnings? The Accounting Review 71, 289-315.

Stoll, Hans R., 1978. The supply of dealer services in securities markets, Journal of Finance 33, 1133-1151.

Wermers, Russ, 1999. Mutual fund herding and the impact on stock prices, Journal of Finance 54, 581-622. 


\section{Appendix A: Brief definitions and sources of main variables}

This table briefly defines the main variables used in the empirical analyses. The data sources are:

(i) CRSP: Center for Research in Security Prices database

(ii) Compustat: North America Annual and Quarterly database

(iii) I/B/E/S: Institutional Brokers' Estimate System database from Thomson Reuters

(iv) 13F: Institutional Holdings database from Thomson Reuters

(v) BEA: Bureau of Economic Analysis Benchmark Input-Output Accounts

(vi) Estimated: Estimated by the authors

\section{Panel A: Stock characteristics}

\begin{tabular}{|c|c|c|}
\hline Variable Name & Description & Source \\
\hline Price & Price at end of previous quarter. & CRSP \\
\hline Market capitalization & $\begin{array}{l}\text { Price times shares outstanding, at end of } \\
\text { previous quarter. }\end{array}$ & CRSP \\
\hline Book-to-market equity & $\begin{array}{l}\text { Annual book value of equity divided by } \\
\text { market value of equity, at end of } \\
\text { previous quarter. }\end{array}$ & Compustat \\
\hline Idiosyncratic volatility & $\begin{array}{l}\text { Idiosyncratic volatility calculated from } \\
\text { daily Fama-French three-factor } \\
\text { regression residuals over a one-year } \\
\text { period, at end of previous month (Ang, } \\
\text { Hodrick, Xing, and Zhang, 2006). }\end{array}$ & CRSP, estimated \\
\hline Amihud illiquidity & $\begin{array}{l}\text { Average of daily absolute value of } \\
\text { return divided by dollar volume over a } \\
\text { one-month period, at end of previous } \\
\text { month, scaled by } 10^{6} \text { (Amihud, 2002). }\end{array}$ & CRSP, estimated \\
\hline NYSE/AMEX volume & $\begin{array}{l}\text { NYSE/AMEX share trading volume (in } \\
\text { thousands), at end of previous month. }\end{array}$ & CRSP \\
\hline NYSE/AMEX turnover & $\begin{array}{l}\text { NYSE/AMEX share turnover (in } \\
\text { percent), at end of previous month. }\end{array}$ & CRSP \\
\hline NASDAQ volume & $\begin{array}{l}\text { NASDAQ share trading volume (in } \\
\text { thousands), at end of previous month. }\end{array}$ & CRSP \\
\hline NASDAQ turnover & $\begin{array}{l}\text { NASDAQ share turnover (in percent), } \\
\text { at end of previous month. }\end{array}$ & CRSP \\
\hline
\end{tabular}




\begin{tabular}{lll}
\hline Earnings surprise & $\begin{array}{l}\text { Standardized unexpected earnings } \\
\text { (SUE) based on seasonal random walk } \\
\text { model with drift, at end of previous } \\
\text { quarter (as in Chan, Jegadeesh, and } \\
\text { Lakonishok, 1996; Sadka, 2006). }\end{array}$ & $\begin{array}{l}\text { Compustat, } \\
\text { estimated }\end{array}$ \\
& $\begin{array}{l}\text { The change in current assets excluding } \\
\text { cash and short-term investments, minus } \\
\text { the change in current liabilities } \\
\text { Oxcluding short-term debt and taxes } \\
\text { payable, minus the change of } \\
\text { depreciation and amortization at end of } \\
\text { previous quarter (as in Sloan, 1996). }\end{array}$ & \\
& Compustat \\
& $\begin{array}{l}\text { The log level change in split-adjusted } \\
\text { shares outstanding, at end of previous } \\
\text { month (as in Fama and French, 2008). }\end{array}$ & \\
\hline
\end{tabular}

\section{Panel B: Stock returns}

\begin{tabular}{|c|c|c|}
\hline Variable Name & Description & Source \\
\hline $\begin{array}{l}\text { Cumulative abnormal return } \\
\text { (CAR) }\end{array}$ & $\begin{array}{l}\text { Daily abnormal return is calculated as } \\
\text { the daily holding period return (RET) } \\
\text { minus the value-weighted market index } \\
\text { return (VWRET); weekly cumulative } \\
\text { abnormal return (CAR) is the } \\
\text { compounded daily abnormal returns } \\
\text { over one week. If there are weeks with } \\
\text { fewer than five trading days (because of } \\
\text { holidays), we scale the CAR by } \\
\text { dividing by the number of trading days } \\
\text { and multiplying by five. }\end{array}$ & CRSP, estimated \\
\hline Return week t-1 & $\begin{array}{l}\text { Weekly holding period return } \\
\text { (compounded daily returns as of the end } \\
\text { of previous week } \mathrm{t}-1 \text { ). }\end{array}$ & CRSP \\
\hline Return month t-1 & $\begin{array}{l}\text { Monthly holding period return at end of } \\
\text { previous month } \mathrm{t}-1 \text {. }\end{array}$ & CRSP \\
\hline Return month $\mathrm{t}-12$ to $\mathrm{t}-2$ & $\begin{array}{l}\text { Past } 11 \text {-month cumulative returns from } \\
\text { t-12 to } t-2 \text {. }\end{array}$ & CRSP \\
\hline Return month $\mathrm{t}-60$ to $\mathrm{t}-13$ & $\begin{array}{l}\text { Past } 48 \text {-month cumulative returns from } \\
\text { t- } 60 \text { to t- } 13 \text {. }\end{array}$ & CRSP \\
\hline
\end{tabular}


Panel C: Institutional ownership

\begin{tabular}{|c|c|c|}
\hline Variable Name & Description & Source \\
\hline Institutional ownership \% & $\begin{array}{l}\text { Shares held by } 13 \mathrm{~F} \text { institutions divided } \\
\text { by total shares outstanding, at end of } \\
\text { previous quarter. }\end{array}$ & $13 \mathrm{~F}$ and $\mathrm{CRSP}$ \\
\hline \# Institutional investors & $\begin{array}{l}\text { Number of institutional investors in a } \\
\text { stock as of previous quarter-end. }\end{array}$ & $13 \mathrm{~F}$ \\
\hline $\begin{array}{l}\text { \# Common institutional } \\
\text { investors }\end{array}$ & $\begin{array}{l}\text { Number of institutional investors } \\
\text { holding both stocks in a pair as of } \\
\text { previous quarter-end. }\end{array}$ & $13 \mathrm{~F}$, estimated \\
\hline $\begin{array}{l}\text { \# Significant common } \\
\text { institutional investors }\end{array}$ & $\begin{array}{l}\text { Number of institutional investors } \\
\text { holding more than the median } \\
\text { institutional holder of both stocks in a } \\
\text { pair as of previous quarter-end. }\end{array}$ & $13 \mathrm{~F}$, estimated \\
\hline
\end{tabular}




\section{Appendix B: Example of stock prediction methodology}

We provide an example using one weekly observation date for a target stock and an economically unrelated stock. Our strategy is to first identify the current position of the two stocks relative to their most recent earnings announcement dates, then identify similar patterns in the historical sequence of earnings announcements, and finally use the two stocks' historical abnormal return relationship to predict one-week-forward CAR for the target stock.

The example target stock is Service Corp International (SCI), which is classified as NAICS code 812210 , funeral homes and funeral services. The example unrelated stock is Driver Harris Corp. (DHC), which is classified as NAICS code 331422, copper wire drawing. ${ }^{23}$ On Friday, January 3, 1997, we conduct the following exercise to predict SCI's return for the following week $(01 / 06 / 1997$ to $01 / 10 / 1997)$.

1. Identify the last earnings announcement date for each firm, and confirm that the unrelated stock (DHC) had the more recent earnings announcement. SCI's last earnings announcement was on 10/18/1996 (for the fiscal quarter 1996Q3), and DHC's last earnings announcement was on 11/11/1996 (for the fiscal quarter 1996Q3). To align weekly intervals across firms and over time, we designate as the first post-announcement week the full week starting from Monday after the second trading day following the earnings announcement. ${ }^{24}$ In this case, DHC's first post-announcement week is from 11/18/1996 to $11 / 22 / 1996$, and SCI's first post-announcement week is from 10/28/1996 to $11 / 01 / 1996$, so we find that there have been seven full weeks between DHC's earnings announcement and today, and ten full weeks between SCI's earnings announcement and today; see Figure 4.

\footnotetext{
${ }^{23}$ SCI's database identifiers are PERMNO $=51625$, GVKEY $=009611$, SIC code $=7261$, and Fama-French 30 -industry code $=22$ (Personal and Business Services). DHC's database identifiers are PERMNO $=31376$, GVKEY $=004083$, SIC code $=3356$, and Fama-French 30-industry code $=12$ (Steel Works).

${ }^{24}$ The two days immediately following the earnings announcement are excluded to minimize the influence of immediate announcement reactions. If the market is closed on Monday, we use the next trading day.
} 
Figure 4: SCI (Target) and DHC (Unrelated) Current period

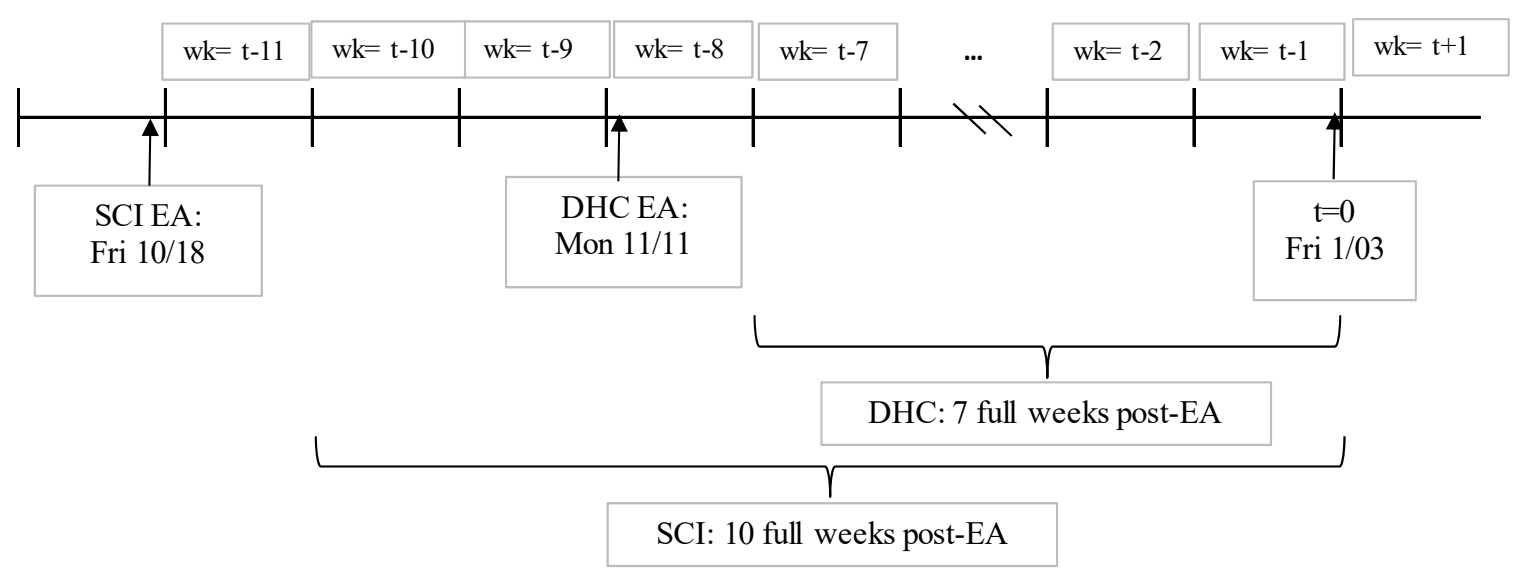

2. Search the previous five years (for the fiscal quarters from 1991Q3 to 1996Q2) for occasions on which DHC was seven full weeks post earnings announcement and SCI was at least eight full weeks (but not more than 12 full weeks) post earnings announcement; that is, the target's post-announcement period must be longer than its unrelated stock's post-announcement period. There may be up to 20 such occasions in the previous five years, depending on how the two firms' earnings announcement dates fell relative to each other in each quarter. ${ }^{25}$ In this example, we find 10 occasions that satisfy the criteria (01/03/1992, 07/10/1992, 10/09/1992, 07/16/1993, 10/22/1993, 07/22/1994, 07/07/1995, 09/22/1995, 07/05/1996, and 09/27/1996).

3. For each of the 10 valid occasions (with seven weeks since the DHC earnings announcement and eight to 12 weeks since the SCI earnings announcement ${ }^{26}$ ), calculate the cumulative abnormal return (CAR) for the unrelated stock (DHC) for each of the seven weeks since its earnings announcement and the unrelated stock's average CAR over the

\footnotetext{
${ }^{25}$ We refer to these situations as "occasions" rather than "events" to avoid confusion with the customary references to earnings announcements themselves as "events."

${ }^{26}$ In this example, the 10 occasions that meet the criteria have 10, 10,11,11, 12, 12, 10, 9, 10, and 9 weeks since the SCI earnings announcements dates, respectively.
} 
seven weeks, and calculate the CAR for the target stock (SCI) in the subsequent week (i.e., the eighth week after the unrelated stock's earnings announcement).

4. Using the CARs for all of the 10 valid occasions in the past five years, regress the target stock SCI's subsequent-week CAR on the average CAR for its unrelated stock DHC over its seven post-earnings-announcement weeks. This regression is estimated with an intercept, as follows:

$$
C A R_{s+1}^{\text {Target }}=\alpha+\beta C A R_{S-7, S-1}^{\text {Unrelated }}+\varepsilon
$$

where the subscript $s$ refers to each of the 10 historical occasions.

5. Calculate the average CAR for DHC over the seven-week post-announcement period ending on $01 / 03 / 1997$, our weekly observation date. Use the regression coefficients from equation (1) to calculate the predicted value for SCI's CAR in the subsequent week, from 01/06/1997 to 01/10/1997. The predicted CAR for the target stock SCI is calculated as:

$$
\text { PredictedCAR } R_{t+1}^{\text {Target }}=\hat{\alpha}+\hat{\beta} C A R_{t-7, t-1}^{\text {Unrelated }}
$$

where the subscript $t$ refers to the point in time at which the target stock's return is being predicted, and $\hat{\alpha}$ and $\hat{\beta}$ are the coefficient estimates from equation (1). 


\section{Table 1: Sample descriptive statistics}

The sample consists of common stocks listed on NYSE/AMEX/NASDAQ from 1980 to 2010. Panel A reports descriptive statistics for the 13,109 stocks in the sample. Cross-sectional statistics of each stock characteristic are calculated at the end of each quarter, and time series averages of the mean and 25th, 50th, and 75th percentile values over the 124 quarters are reported in Panel A. Panel B presents descriptive statistics for the pairs of economically unrelated stocks. Number of pairs is the number of economically unrelated pairs; Common institutional investors are defined as the same institution holding both stocks in a stock pair at the end of the prior quarter; Significant common institutional investors hold more than the median institutional holder of each stock in the pair. Cross-sectional statistics are calculated across all economically unrelated pairs of stocks in each week, and time-series averages of the mean and 25th, 50th, and 75th percentile values over the 1617 weeks are reported in Panel B.

\begin{tabular}{|c|c|c|c|c|}
\hline \multicolumn{5}{|l|}{ Panel A: Quarterly stock characteristics } \\
\hline & Mean & $25^{\text {th }}$ Percentile & $50^{\text {th }}$ Percentile & $75^{\text {th }}$ Percentile \\
\hline Price $(\$)$ & 36.37 & 10.86 & 18.76 & 30.65 \\
\hline Market capitalization (\$ million) & $2,118.6$ & 92.0 & 289.9 & $1,056.6$ \\
\hline Book-to-market ratio & 0.78 & 0.41 & 0.68 & 1.01 \\
\hline Cumulative monthly return, months t-12 to $\mathrm{t}-1(\%)$ & 22.7 & -7.9 & 12.0 & 37.5 \\
\hline Cumulative monthly return, months $\mathrm{t}-60$ to $\mathrm{t}-13(\%)$ & 115.9 & 11.8 & 66.2 & 146.0 \\
\hline Institutional ownership (\%) & 41.2 & 21.2 & 41.5 & 60.3 \\
\hline Number of institutional investors & 93 & 20 & 50 & 112 \\
\hline \multicolumn{5}{|l|}{ Panel B: Weekly pairs of economically unrelated stocks } \\
\hline & Mean & $25^{\text {th }}$ Percentile & $50^{\text {th }}$ Percentile & $75^{\text {th }}$ Percentile \\
\hline Number of pairs & 215 & 85 & 175 & 312 \\
\hline \multicolumn{5}{|l|}{ Number of pairs with } \\
\hline - significant common institutional investors & 188 & 71 & 151 & 274 \\
\hline - common institutional investors & 206 & 79 & 166 & 299 \\
\hline - no significant common institutional investors & 20 & 5 & 11 & 22 \\
\hline - no common institutional investors & 10 & 2 & 6 & 11 \\
\hline Significant common institutional investors per stock pair & 10 & 2 & 6 & 13 \\
\hline Common institutional investors per stock pair & 27 & 7 & 17 & 34 \\
\hline
\end{tabular}




\section{Table 2: Portfolio characteristics}

In every week, stocks are sorted into five industry-neutral portfolios based on predicted cumulative abnormal returns (CARs) using information from stocks in unrelated industries. Portfolio characteristics are calculated as the simple averages of firm-level characteristics. Panel A reports the time-series average of each quintile's characteristics over the sample period, 1980-2010, with all characteristics calculated as of the end of the previous month. Panel B shows weekly portfolio return autocorrelations; Rho_n refers to the order-n autocorrelation.

\begin{tabular}{|c|c|c|c|c|c|}
\hline \multicolumn{6}{|c|}{ Panel A: Portfolio characteristics } \\
\hline Quintile & Size $(\$ m n)$ & Book-to-Mkt & $\begin{array}{c}\text { Return }(\%) \\
\text { week t-1 }\end{array}$ & $\begin{array}{c}\text { Return (\%) } \\
\text { month t-12 to t-2 }\end{array}$ & $\begin{array}{l}\text { Idiosyncratic } \\
\text { Volatility (\%) }\end{array}$ \\
\hline 1 (Low) & 1,574 & 0.90 & 1.53 & 13.22 & 2.66 \\
\hline 2 & 2,731 & 0.83 & 1.48 & 14.95 & 2.26 \\
\hline 3 & 3,070 & 0.79 & 1.45 & 18.20 & 2.22 \\
\hline 4 & 2,667 & 0.75 & 1.45 & 22.70 & 2.33 \\
\hline 5 (High) & 1,621 & 0.72 & 1.54 & 35.56 & 2.77 \\
\hline Quintile & $\begin{array}{l}\text { Amihud Illiquidity } \\
\left(\times 10^{6}\right) \\
\end{array}$ & $\begin{array}{c}\text { NYSE/AMEX } \\
\text { Volume } \\
\text { (shares, 000) } \\
\end{array}$ & $\begin{array}{c}\text { NYSE/AMEX } \\
\text { Turnover } \\
\end{array}$ & $\begin{array}{c}\text { NASDAQ } \\
\text { Volume } \\
\text { (shares, 000) }\end{array}$ & $\begin{array}{r}\text { NASDAQ } \\
\text { Turnover } \\
\end{array}$ \\
\hline 1 (Low) & 2.29 & 12,214 & 9.36 & 6,442 & 5.86 \\
\hline 2 & 1.54 & 13,379 & 8.93 & 7,901 & 5.70 \\
\hline 3 & 1.34 & 13,587 & 9.00 & 8,687 & 5.83 \\
\hline 4 & 1.24 & 12,631 & 9.41 & 8,925 & 6.09 \\
\hline 5 (High) & 1.31 & 11,256 & 10.67 & 8,112 & 6.54 \\
\hline
\end{tabular}

\begin{tabular}{cccccc}
\hline \multicolumn{7}{l}{ Panel B: Portfolio weekly return autocorrelations } & & & \\
\hline Quintile & Rho_1 & Rho_2 & Rho_3 & Rho_4 & Rho_8 \\
\hline 1 (Low) & 0.002 & 0.047 & -0.071 & -0.004 & 0.008 \\
2 & -0.028 & 0.067 & -0.053 & -0.017 & -0.002 \\
3 & -0.023 & 0.035 & -0.066 & -0.019 & -0.019 \\
4 & -0.047 & 0.054 & -0.038 & -0.013 & -0.019 \\
5 (High) & -0.032 & 0.026 & -0.016 & 0.009 & -0.015 \\
\hline
\end{tabular}


Table 3: Return predictability among economically unrelated stock pairs

This table reports the weekly excess returns and alphas (in percent) of industry-neutral portfolios of stocks sorted based on predicted cumulative abnormal returns (CARs) from all economically unrelated stock pairs (Panel A) and for all same industry stock pairs (Panel B). Quintile 1 has the lowest predicted CARs, while quintile 5 has the highest. For each quintile of stocks, we report the value-weighted excess return above the risk-free rate $(E R)$, and the valueweighted alpha from CAPM (CAPM), Fama-French three-factor (FF3), and Fama-French-Carhart four-factor (FFC4) regressions. The average number of stocks in each portfolio is reported under \# Stocks. The row labeled Q5-Q1 shows the difference between Quintile 5 and Quintile 1. $t$-statistics are reported in parentheses below the coefficient estimates.

\begin{tabular}{|c|c|c|c|c|c|}
\hline \multicolumn{6}{|c|}{ Panel A: Economically unrelated stock pairs } \\
\hline Quintile & ER & CAPM & FF3 & FFC4 & \# Stocks \\
\hline \multirow[t]{2}{*}{1 (Low) } & 0.020 & -0.106 & -0.129 & -0.119 & 356 \\
\hline & $(0.3)$ & $(-4.5)$ & $(-5.7)$ & $(-5.3)$ & \\
\hline \multirow[t]{2}{*}{2} & 0.064 & -0.054 & -0.057 & -0.054 & 368 \\
\hline & $(1.1)$ & $(-3.0)$ & $(-3.2)$ & $(-3.1)$ & \\
\hline \multirow[t]{2}{*}{3} & 0.114 & -0.004 & -0.003 & -0.001 & 368 \\
\hline & $(2.0)$ & $(-0.2)$ & $(-0.2)$ & $(-0.1)$ & \\
\hline \multirow[t]{2}{*}{4} & 0.172 & 0.044 & 0.047 & 0.044 & 368 \\
\hline & $(2.8)$ & $(2.6)$ & $(2.8)$ & $(2.6)$ & \\
\hline \multirow[t]{2}{*}{5 (High) } & 0.211 & 0.070 & 0.077 & 0.076 & 380 \\
\hline & (3.1) & $(3.1)$ & (3.6) & (3.5) & \\
\hline \multirow[t]{2}{*}{ Q5 - Q1 } & 0.191 & 0.176 & 0.206 & 0.195 & \\
\hline & (5.3) & (4.9) & (6.0) & (5.7) & \\
\hline
\end{tabular}

\begin{tabular}{cccccc}
\hline Panel B: Same industry stock pairs & & & \\
\hline Quintile & ER & CAPM & FF3 & FFC4 & \# Stocks \\
\hline 1 (Low) & 0.058 & -0.067 & -0.088 & -0.078 & 362 \\
& $(0.9)$ & $(-2.9)$ & $(-4.0)$ & $(-3.5)$ & \\
2 & 0.083 & -0.036 & -0.042 & -0.037 & 374 \\
& $(1.5)$ & $(-2.1)$ & $(-2.5)$ & $(-2.2)$ & \\
3 & 0.115 & -0.004 & -0.007 & -0.006 & 374 \\
& $(2.0)$ & $(-0.3)$ & $(-0.4)$ & $(-0.4)$ & \\
4 & 0.165 & 0.036 & 0.038 & 0.036 & 374 \\
& $(2.7)$ & $(2.2)$ & $(2.3)$ & $(2.2)$ & \\
5 (High) & 0.199 & 0.061 & 0.067 & 0.065 & 386 \\
& $(3.0)$ & $(3.1)$ & $(3.4)$ & $(3.3)$ & \\
\hline Q5 - Q1 & 0.140 & 0.128 & 0.155 & 0.143 & \\
& $(4.2)$ & $(3.9)$ & $(4.9)$ & $(4.5)$ & \\
\hline
\end{tabular}


This table reports the weekly excess returns and alphas (in percent) of industry-neutral portfolios of stocks sorted based on predicted cumulative abnormal returns (CARs) from economically unrelated stock pairs (Panels A and C) and same industry stock pairs (Panels B and D). Quintile 1 has the lowest predicted CARs, while quintile 5 has the highest. For each quintile of stocks, we report the value-weighted excess return above the risk-free rate (ER), and the value-weighted alpha from CAPM (CAPM), Fama-French three-

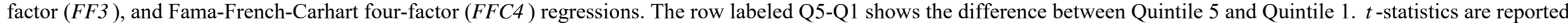
in parentheses below the coefficient estimates. Each panel reports the predictability results using subsets of the economically unrelated stock pairs to predict returns. Panels A and B report predictability results using economically unrelated stock pairs with at least one significant common institutional owner ( With Significant Common Institutional Owners ) versus without any significant common institutional owners (Without Significant Common Institutional Owners ), and the difference, where significant common institutional ownership is defined as an institution holding more of each stock than the median institutional holder of each stock. Panels $\mathrm{C}$ and $\mathrm{D}$ report the predictability results using same industry stock pairs with and without common institutional owners (With Common Institutional Owners and Without Common Institutional Owners , respectively).

\section{Panel A: Economically unrelated stock pairs with versus without significant common institutional owners}

$$
\text { With Significant }
$$

Common Institutional Owners

\begin{tabular}{ccccc}
\cline { 2 - 5 } Quintile & ER & CAPM & FF3 & FFC4 \\
\cline { 2 - 5 } 1 (Low) & 0.023 & -0.116 & -0.140 & -0.131 \\
& $(0.3)$ & $(-4.2)$ & $(-5.5)$ & $(-5.1)$ \\
2 & 0.072 & -0.056 & -0.060 & -0.058 \\
& $(1.2)$ & $(-2.8)$ & $(-3.1)$ & $(-3.0)$ \\
3 & 0.132 & 0.001 & -0.003 & -0.002 \\
4 & $(2.1)$ & $(0.1)$ & $(-0.2)$ & $(-0.1)$ \\
& 0.192 & 0.052 & 0.052 & 0.052 \\
5 (High) & $(2.9)$ & $(2.9)$ & $(2.9)$ & $(2.8)$ \\
& 0.220 & 0.064 & 0.071 & 0.071 \\
\hline Q5 - Q1 & $(2.9)$ & $(2.5)$ & $(2.9)$ & $(2.9)$ \\
& 0.198 & 0.180 & 0.211 & 0.202 \\
& $(4.8)$ & $(4.4)$ & $(5.5)$ & $(5.3)$ \\
\hline
\end{tabular}

$$
\text { Without Significant }
$$

Common Institutional Owners

\begin{tabular}{cccc}
\hline ER & CAPM & FF3 & FFC4 \\
\hline 0.118 & -0.025 & -0.035 & -0.035 \\
$(1.6)$ & $(-0.8)$ & $(-1.1)$ & $(-1.1)$ \\
0.130 & -0.001 & -0.014 & -0.012 \\
$(1.9)$ & $(-0.1)$ & $(-0.5)$ & $(-0.5)$ \\
0.135 & 0.001 & -0.014 & -0.011 \\
$(2.0)$ & $(0.0)$ & $(-0.5)$ & $(-0.4)$ \\
0.160 & 0.024 & 0.014 & 0.012 \\
$(2.3)$ & $(0.9)$ & $(0.5)$ & $(0.4)$ \\
0.161 & 0.013 & 0.007 & 0.005 \\
$(2.2)$ & $(0.5)$ & $(0.3)$ & $(0.2)$ \\
0.043 & 0.039 & 0.042 & 0.040 \\
$(1.2)$ & $(1.0)$ & $(1.1)$ & $(1.1)$
\end{tabular}

\begin{tabular}{|c|c|c|c|}
\hline ER & CAPM & FF3 & FFC4 \\
\hline-0.096 & -0.091 & -0.105 & -0.096 \\
\hline$(-2.4)$ & $(-2.3)$ & $(-2.7)$ & $(-2.5)$ \\
\hline-0.058 & -0.054 & -0.047 & -0.046 \\
\hline$(-1.8)$ & $(-1.7)$ & $(-1.5)$ & $(-1.5)$ \\
\hline-0.003 & 0.001 & 0.011 & 0.009 \\
\hline$(-0.1)$ & $(0.0)$ & (0.3) & (0.3) \\
\hline 0.031 & 0.028 & 0.038 & 0.039 \\
\hline$(1.0)$ & $(0.9)$ & $(1.2)$ & (1.3) \\
\hline 0.059 & 0.051 & 0.064 & 0.066 \\
\hline (1.8) & (1.6) & $(2.0)$ & (2.1) \\
\hline 0.155 & 0.142 & 0.169 & 0.162 \\
\hline$(3.0)$ & $(2.8)$ & (3.4) & (3.3) \\
\hline
\end{tabular}

With - Without Difference 
Panel B: Same industry stock pairs with versus without significant common institutional owners

With Significant

Common Institutional Owners

\begin{tabular}{|c|c|c|c|c|}
\hline \multirow[b]{2}{*}{ Quintile } & \\
\hline & ER & CAPM & FF3 & FFC4 \\
\hline \multirow[t]{2}{*}{1 (Low) } & 0.066 & -0.070 & -0.089 & -0.080 \\
\hline & $(1.0)$ & $(-2.7)$ & $(-3.6)$ & $(-3.2)$ \\
\hline \multirow[t]{2}{*}{2} & 0.100 & -0.030 & -0.036 & -0.033 \\
\hline & (1.6) & $(-1.5)$ & $(-1.9)$ & $(-1.7)$ \\
\hline \multirow[t]{2}{*}{3} & 0.127 & -0.002 & -0.006 & -0.006 \\
\hline & $(2.0)$ & $(-0.1)$ & $(-0.3)$ & $(-0.3)$ \\
\hline \multirow[t]{2}{*}{4} & 0.187 & 0.046 & 0.047 & 0.046 \\
\hline & $(2.8)$ & $(2.7)$ & $(2.7)$ & (2.6) \\
\hline \multirow[t]{2}{*}{5 (High) } & 0.213 & 0.062 & 0.068 & 0.066 \\
\hline & (2.9) & $(2.7)$ & (3.1) & (2.9) \\
\hline \multirow[t]{2}{*}{ Q5 - Q1 } & 0.147 & 0.132 & 0.157 & 0.145 \\
\hline & (3.9) & (3.6) & (4.4) & $(4.1)$ \\
\hline
\end{tabular}

Without Significant

Common Institutional Owners

\begin{tabular}{|c|c|c|c|c|c|c|c|}
\hline ER & CAPM & FF3 & FFC4 & ER & CAPM & FF3 & FFC4 \\
\hline 0.101 & -0.056 & -0.089 & -0.069 & -0.035 & -0.015 & 0.000 & -0.011 \\
\hline$(1.2)$ & $(-1.2)$ & $(-2.0)$ & $(-1.6)$ & $(-0.7)$ & $(-0.3)$ & $(0.0)$ & $(-0.2)$ \\
\hline 0.111 & -0.036 & -0.058 & -0.048 & -0.010 & 0.007 & 0.022 & 0.015 \\
\hline (1.4) & $(-0.9)$ & $(-1.4)$ & $(-1.2)$ & $(-0.2)$ & $(0.2)$ & $(0.5)$ & $(0.3)$ \\
\hline 0.159 & 0.022 & -0.001 & 0.007 & -0.032 & -0.024 & -0.005 & -0.013 \\
\hline (2.1) & $(0.6)$ & $(0.0)$ & $(0.2)$ & $(-0.8)$ & $(-0.6)$ & $(-0.1)$ & $(-0.3)$ \\
\hline 0.141 & -0.004 & -0.023 & -0.012 & 0.046 & 0.050 & 0.070 & 0.058 \\
\hline (1.8) & $(-0.1)$ & $(-0.6)$ & $(-0.3)$ & (1.1) & $(1.2)$ & (1.7) & (1.4) \\
\hline 0.194 & 0.040 & 0.022 & 0.034 & 0.019 & 0.022 & 0.047 & 0.031 \\
\hline (2.4) & $(1.0)$ & $(0.5)$ & $(0.8)$ & $(0.4)$ & $(0.5)$ & (1.1) & $(0.7)$ \\
\hline 0.093 & 0.096 & 0.111 & 0.104 & 0.054 & 0.036 & 0.046 & 0.042 \\
\hline$(1.8)$ & (1.9) & $(2.2)$ & $(2.0)$ & $(0.9)$ & $(0.6)$ & $(0.8)$ & $(0.7)$ \\
\hline
\end{tabular}

Panel C: Economically unrelated stock pairs with versus without common institutional owners

\begin{tabular}{|c|c|c|c|c|c|c|c|c|c|c|c|c|}
\hline \multirow[b]{2}{*}{ Quintile } & \multicolumn{4}{|c|}{ With Common Institutional Owners } & \multicolumn{4}{|c|}{ Without Common Institutional Owners } & \multicolumn{4}{|c|}{ With - Without Difference } \\
\hline & ER & CAPM & FF3 & FFC4 & ER & CAPM & FF3 & FFC4 & ER & CAPM & FF3 & FFC4 \\
\hline \multirow[t]{2}{*}{1 (Low) } & 0.010 & -0.119 & -0.138 & -0.132 & 0.159 & 0.048 & 0.034 & 0.023 & -0.149 & -0.168 & -0.172 & -0.155 \\
\hline & $(0.2)$ & $(-4.7)$ & $(-5.7)$ & $(-5.4)$ & $(2.1)$ & $(0.9)$ & $(0.6)$ & $(0.4)$ & $(-2.5)$ & $(-2.8)$ & $(-2.9)$ & $(-2.6)$ \\
\hline \multirow[t]{2}{*}{2} & 0.069 & -0.052 & -0.057 & -0.056 & 0.125 & 0.013 & 0.006 & 0.001 & -0.056 & -0.066 & -0.063 & -0.057 \\
\hline & $(1.1)$ & $(-2.7)$ & $(-3.0)$ & $(-2.9)$ & $(1.7)$ & $(0.3)$ & $(0.1)$ & $(0.0)$ & $(-1.0)$ & $(-1.2)$ & $(-1.2)$ & $(-1.1)$ \\
\hline \multirow[t]{2}{*}{3} & 0.126 & 0.003 & -0.001 & 0.002 & 0.135 & 0.027 & 0.022 & 0.011 & -0.009 & -0.024 & -0.023 & -0.009 \\
\hline & $(2.0)$ & $(0.1)$ & $(-0.0)$ & $(0.1)$ & (1.8) & $(0.5)$ & $(0.4)$ & $(0.2)$ & $(-0.2)$ & $(-0.4)$ & $(-0.4)$ & $(-0.2)$ \\
\hline \multirow[t]{2}{*}{4} & 0.193 & 0.059 & 0.057 & 0.056 & 0.132 & 0.018 & 0.016 & -0.001 & 0.060 & 0.041 & 0.041 & 0.057 \\
\hline & (2.9) & (3.3) & $(3.2)$ & (3.2) & (1.9) & $(0.4)$ & $(0.4)$ & $(-0.0)$ & $(1.2)$ & $(0.9)$ & $(0.9)$ & $(1.2)$ \\
\hline \multirow[t]{2}{*}{5 (High) } & 0.211 & 0.062 & 0.067 & 0.067 & 0.195 & 0.065 & 0.059 & 0.048 & 0.016 & -0.004 & 0.007 & 0.019 \\
\hline & $(2.8)$ & $(2.4)$ & (2.8) & (2.8) & $(2.5)$ & $(1.4)$ & (1.3) & $(1.0)$ & $(0.3)$ & $(-0.1)$ & $(0.2)$ & $(0.4)$ \\
\hline \multirow[t]{2}{*}{ Q5 - Q1 } & 0.201 & 0.181 & 0.205 & 0.199 & 0.036 & 0.017 & 0.026 & 0.025 & 0.165 & 0.164 & 0.180 & 0.174 \\
\hline & $(5.0)$ & $(4.7)$ & (5.5) & (5.3) & $(0.5)$ & $(0.3)$ & $(0.4)$ & $(0.4)$ & $(2.2)$ & (2.2) & $(2.4)$ & (2.3) \\
\hline
\end{tabular}


Panel D: Same industry stock pairs with versus without common institutional owners

\begin{tabular}{|c|c|c|c|c|c|c|c|c|c|c|c|c|}
\hline \multirow[b]{2}{*}{ Quintile } & \multicolumn{4}{|c|}{ With Common Institutional Owners } & \multicolumn{4}{|c|}{ Without Common Institutional Owners } & \multicolumn{4}{|c|}{ With - Without Difference } \\
\hline & ER & CAPM & FF3 & FFC4 & ER & CAPM & FF3 & FFC4 & ER & CAPM & FF3 & FFC4 \\
\hline \multirow[t]{2}{*}{1 (Low) } & 0.046 & -0.091 & -0.109 & -0.101 & 0.051 & -0.093 & -0.095 & -0.091 & -0.005 & 0.003 & -0.014 & -0.010 \\
\hline & $(0.7)$ & $(-3.5)$ & $(-4.4)$ & $(-4.1)$ & $(0.6)$ & $(-2.0)$ & $(-2.1)$ & $(-2.0)$ & $(-0.1)$ & $(0.1)$ & $(-0.3)$ & $(-0.2)$ \\
\hline \multirow[t]{2}{*}{2} & 0.100 & -0.029 & -0.036 & -0.032 & 0.129 & -0.009 & -0.001 & 0.011 & -0.029 & -0.020 & -0.035 & -0.043 \\
\hline & (1.6) & $(-1.5)$ & $(-1.9)$ & $(-1.7)$ & (1.7) & $(-0.2)$ & $(0.0)$ & $(0.2)$ & $(-0.6)$ & $(-0.4)$ & $(-0.7)$ & $(-0.9)$ \\
\hline \multirow[t]{2}{*}{3} & 0.120 & -0.008 & -0.013 & -0.012 & 0.134 & -0.006 & -0.002 & 0.013 & -0.014 & -0.002 & -0.011 & -0.025 \\
\hline & (1.9) & $(-0.5)$ & $(-0.7)$ & $(-0.7)$ & (1.7) & $(-0.2)$ & $(0.0)$ & $(0.3)$ & $(-0.3)$ & $(0.0)$ & $(-0.3)$ & $(-0.6)$ \\
\hline \multirow[t]{2}{*}{4} & 0.197 & 0.056 & 0.057 & 0.054 & 0.141 & -0.007 & -0.000 & 0.012 & 0.056 & 0.063 & 0.057 & 0.042 \\
\hline & (2.9) & (3.1) & (3.2) & (3.1) & (1.7) & $(-0.2)$ & $(0.0)$ & $(0.3)$ & $(1.2)$ & (1.3) & $(1.2)$ & (0.9) \\
\hline \multirow[t]{2}{*}{5 (High) } & 0.216 & 0.065 & 0.072 & 0.069 & 0.217 & 0.072 & 0.072 & 0.082 & -0.002 & -0.007 & -0.001 & -0.013 \\
\hline & (2.9) & $(2.9)$ & (3.2) & (3.1) & (2.7) & (1.5) & (1.6) & (1.8) & $(0.0)$ & $(-0.1)$ & $(0.0)$ & $(-0.3)$ \\
\hline \multirow[t]{2}{*}{ Q5 - Q1 } & 0.170 & 0.156 & 0.181 & 0.170 & 0.167 & 0.165 & 0.167 & 0.173 & 0.003 & -0.009 & 0.014 & -0.004 \\
\hline & (4.5) & $(4.2)$ & (5.1) & (4.8) & (2.9) & (2.9) & (2.9) & (3.0) & $(0.0)$ & $(-0.1)$ & $(0.2)$ & $(-0.1)$ \\
\hline
\end{tabular}




\section{Table 5: Seasonality tied to common rebalancing weeks}

This table reports the weekly excess returns and alphas (in percent) of industry-neutral portfolios of stocks sorted based on predicted cumulative abnormal returns (CARs) from economically unrelated stock pairs, separating Russell index rebalancing weeks (Panel A), the last week of each calendar quarter (Panel B), and the last week of each month (Panel C) from other weeks. Russell rebalancing week is defined as the week with the portfolio formed on the last Friday in June unless that falls on June 29 or 30, in which case it is formed the prior Friday. Last week of the calendar quarter (month) is defined as the week containing the last trading day of the calendar quarter (month). Quintile 1 has the lowest predicted CARs, while quintile 5 has the highest. For each quintile of stocks, we report the valueweighted excess return above the risk-free rate $(E R)$ and the value-weighted alphas from CAPM (CAPM), the Fama-French three-factor model (FF3), and the Fama-French-Carhart four-factor model (FFC4). The average number of stocks in each portfolio is reported under \# Stocks. The row labeled Q5-Q1 shows the difference between quintile 5 and quintile 1. $t$-statistics are reported in parentheses below the coefficient estimates.

\begin{tabular}{|c|c|c|c|c|c|c|c|c|c|c|c|}
\hline \multicolumn{12}{|c|}{ Panel A: Russell index rebalancing weeks } \\
\hline \multicolumn{6}{|c|}{$\begin{array}{ll}\text { Russell rebalancing week } \\
\end{array}$} & \multicolumn{6}{|c|}{ All other weeks } \\
\hline Quintile & ER & CAPM & FF3 & FFC4 & \# Stocks & Quintile & ER & CAPM & FF3 & FFC4 & \# Stocks \\
\hline \multirow[t]{2}{*}{1 (Low) } & -0.348 & -0.285 & -0.292 & -0.273 & 432 & 1 (Low) & -0.070 & -0.102 & -0.129 & -0.115 & 339 \\
\hline & $(-1.0)$ & $(-1.8)$ & $(-1.8)$ & $(-1.5)$ & & & $(-1.1)$ & $(-4.3)$ & $(-5.7)$ & $(-5.2)$ & \\
\hline \multirow[t]{2}{*}{2} & -0.168 & -0.104 & -0.137 & -0.189 & 444 & 2 & -0.020 & -0.049 & -0.050 & -0.046 & 351 \\
\hline & $(-0.5)$ & $(-1.1)$ & $(-1.3)$ & $(-1.6)$ & & & $(-0.3)$ & $(-2.7)$ & $(-2.8)$ & $(-2.6)$ & \\
\hline \multirow[t]{2}{*}{3} & -0.156 & -0.089 & 0.047 & 0.122 & 445 & 3 & 0.037 & 0.008 & 0.016 & 0.016 & 351 \\
\hline & $(-0.5)$ & $(-0.9)$ & $(0.5)$ & $(1.2)$ & & & $(0.6)$ & $(0.4)$ & $(0.9)$ & $(0.9)$ & \\
\hline \multirow[t]{2}{*}{4} & -0.162 & -0.092 & 0.018 & 0.054 & 444 & 4 & 0.072 & 0.041 & 0.050 & 0.045 & 351 \\
\hline & $(-0.5)$ & $(-1.0)$ & $(0.2)$ & $(0.5)$ & & & $(1.2)$ & $(2.4)$ & (2.9) & (2.7) & \\
\hline \multirow[t]{2}{*}{5 (High) } & 0.163 & 0.243 & 0.186 & 0.278 & 456 & 5 (High) & 0.101 & 0.067 & 0.071 & 0.068 & 363 \\
\hline & $(0.4)$ & $(2.2)$ & $(1.7)$ & (2.3) & & & (1.4) & (3.0) & (3.3) & (3.1) & \\
\hline \multirow[t]{2}{*}{ Q5 - Q1 } & 0.512 & 0.527 & 0.478 & 0.551 & & Q5 - Q1 & 0.171 & 0.168 & 0.200 & 0.183 & \\
\hline & (2.9) & (3.3) & $(2.7)$ & $(2.7)$ & & & $(4.7)$ & (4.7) & (5.9) & (5.4) & \\
\hline
\end{tabular}




\begin{tabular}{|c|c|c|c|c|c|c|c|c|c|c|c|}
\hline \multicolumn{12}{|c|}{ Panel B: Calendar quarters } \\
\hline \multicolumn{6}{|c|}{$\begin{array}{ll}\text { Last week } \\
\end{array}$} & \multicolumn{6}{|c|}{ All other weeks } \\
\hline Quintile & ER & CAPM & FF3 & FFC4 & \# Stocks & Quintile & ER & CAPM & FF3 & FFC4 & \# Stocks \\
\hline \multirow[t]{2}{*}{1 (Low) } & 0.174 & 0.004 & -0.114 & -0.077 & 421 & 1 (Low) & 0.094 & -0.015 & -0.050 & -0.027 & 349 \\
\hline & $(0.9)$ & $(0.1)$ & $(-2.3)$ & $(-1.7)$ & & & $(1.5)$ & $(-0.5)$ & $(-3.0)$ & $(-1.8)$ & \\
\hline \multirow[t]{2}{*}{2} & 0.249 & 0.085 & -0.014 & 0.016 & 433 & 2 & 0.129 & 0.023 & -0.010 & 0.005 & 361 \\
\hline & $(1.4)$ & $(1.2)$ & $(-0.3)$ & $(0.4)$ & & & $(2.2)$ & $(1.0)$ & $(-0.7)$ & $(0.4)$ & \\
\hline \multirow[t]{2}{*}{3} & 0.341 & 0.176 & 0.081 & 0.102 & 433 & 3 & 0.156 & 0.049 & 0.019 & 0.033 & 361 \\
\hline & (1.9) & $(2.7)$ & $(2.1)$ & $(2.8)$ & & & $(2.7)$ & $(2.2)$ & $(1.4)$ & $(2.6)$ & \\
\hline \multirow[t]{2}{*}{4} & 0.368 & 0.197 & 0.088 & 0.109 & 433 & 4 & 0.187 & 0.075 & 0.049 & 0.063 & 361 \\
\hline & $(1.9)$ & $(2.8)$ & $(2.3)$ & $(3.0)$ & & & $(3.0)$ & $(3.2)$ & (3.6) & $(4.8)$ & \\
\hline \multirow[t]{2}{*}{5 (High) } & 0.472 & 0.288 & 0.153 & 0.170 & 445 & 5 (High) & 0.218 & 0.093 & 0.078 & 0.089 & 372 \\
\hline & $(2.3)$ & (3.3) & (3.3) & (3.7) & & & (3.1) & (3.3) & (5.3) & $(6.2)$ & \\
\hline \multirow[t]{2}{*}{ Q5 - Q1 } & 0.298 & 0.283 & 0.267 & 0.247 & & $\mathrm{Q} 5-\mathrm{Q} 1$ & 0.123 & 0.108 & 0.128 & 0.116 & \\
\hline & $(5.2)$ & (5.1) & $(5.2)$ & (4.9) & & & $(6.0)$ & (5.6) & (7.1) & $(6.6)$ & \\
\hline \multicolumn{12}{|c|}{ Panel C: Calendar months } \\
\hline \multicolumn{6}{|c|}{$\begin{array}{ll}\text { Last week } \\
\end{array}$} & \multicolumn{6}{|c|}{ All other weeks } \\
\hline Quintile & ER & CAPM & FF3 & FFC4 & \# Stocks & Quintile & ER & CAPM & FF3 & FFC4 & \# Stocks \\
\hline \multirow[t]{2}{*}{1 (Low) } & 0.401 & -0.085 & -0.099 & -0.111 & 347 & 1 (Low) & -0.095 & -0.108 & -0.132 & -0.120 & 359 \\
\hline & $(3.2)$ & $(-1.6)$ & $(-1.9)$ & $(-2.1)$ & & & $(-1.3)$ & $(-4.1)$ & $(-5.3)$ & $(-4.9)$ & \\
\hline \multirow[t]{2}{*}{2} & 0.377 & -0.089 & -0.090 & -0.101 & 358 & 2 & -0.031 & -0.042 & -0.047 & -0.043 & 371 \\
\hline & $(3.2)$ & $(-2.4)$ & $(-2.4)$ & $(-2.7)$ & & & $(-0.5)$ & $(-2.1)$ & $(-2.4)$ & $(-2.2)$ & \\
\hline \multirow[t]{2}{*}{3} & 0.436 & -0.037 & -0.047 & -0.039 & 359 & 3 & 0.017 & 0.005 & 0.008 & 0.008 & 371 \\
\hline & (3.7) & $(-1.0)$ & $(-1.3)$ & $(-1.1)$ & & & $(0.3)$ & $(0.3)$ & $(0.4)$ & $(0.4)$ & \\
\hline \multirow[t]{2}{*}{4} & 0.553 & 0.023 & 0.008 & 0.015 & 358 & 4 & 0.057 & 0.044 & 0.050 & 0.046 & 371 \\
\hline & $(4.2)$ & $(0.6)$ & $(0.2)$ & $(0.4)$ & & & $(0.8)$ & $(2.3)$ & $(2.7)$ & $(2.5)$ & \\
\hline \multirow[t]{2}{*}{5 (High) } & 0.653 & 0.073 & 0.077 & 0.082 & 370 & 5 (High) & 0.077 & 0.064 & 0.073 & 0.071 & 382 \\
\hline & $(4.4)$ & $(1.5)$ & $(1.6)$ & $(1.7)$ & & & $(1.0)$ & $(2.5)$ & (3.0) & (2.9) & \\
\hline \multirow[t]{2}{*}{$\mathrm{Q} 5$ - Q1 } & 0.252 & 0.158 & 0.175 & 0.193 & & Q5 - Q1 & 0.173 & 0.171 & 0.205 & 0.191 & \\
\hline & (3.2) & $(2.0)$ & $(2.3)$ & $(2.5)$ & & & $(4.3)$ & (4.3) & $(5.4)$ & (5.1) & \\
\hline
\end{tabular}


Table 6: Predicted returns and changes in institutional holdings

This table reports the quarterly changes in institutional holdings of portfolios sorted based on predicted cumulative abnormal returns (CARs), where each quintile contains only those stocks that are consistently ranked in the same quintile throughout the quarter. In Panel A we select stocks that are ranked in a given quintile for at least $75 \%$ of the weeks in a quarter, and in Panel B we select stocks that are ranked in a given quintile for at least $50 \%$ of the weeks in the quarter. Quintile 1 has the lowest predicted CARs, while quintile 5 has the highest. For each quintile of stocks, we report the change in percentage insitutional ownership over the same quarter. The row labeled Q5-Q1 shows the difference between quintile 5 and quintile 1, followed by the $t$-statistic, signed rank statistic, and the p-values for each test in parentheses.

\begin{tabular}{|c|c|}
\hline $\begin{array}{l}\text { Panel A: Change in institu } \\
\text { quarter }\end{array}$ & r stocks in same quintile for at least $75 \%$ of weeks in \\
\hline Quintile & Change in Percentage Institutional Ownership (\%) \\
\hline 1 (Low) & -0.2437 \\
\hline 2 & 0.2088 \\
\hline 3 & 0.0824 \\
\hline 4 & 0.6765 \\
\hline 5 (High) & 0.9531 \\
\hline Q5 - Q1 & 1.2394 \\
\hline t-statistic & 2.91 \\
\hline (p-value $)$ & $(0.00)$ \\
\hline signed rank statistic & 1.58.E+03 \\
\hline (p-value $)$ & $(0.00)$ \\
\hline
\end{tabular}

\section{Panel B: Change in institutional holdings for stocks in same quintile for at least $50 \%$ of weeks in} quarter

\begin{tabular}{cc}
\hline Quintile & Change in Percentage Institutional Ownership (\%) \\
\hline 1 (Low) & 0.1987 \\
2 & 0.2770 \\
3 & 0.2529 \\
4 & 0.3099 \\
5 (High) & 0.4422 \\
\hline Q5 - Q1 & 0.2434 \\
t-statistic & 8.79 \\
(p-value) & $0.00)$ \\
signed rank statistic & $2.94 . \mathrm{E}+03$ \\
(p-value) & $(0.00)$ \\
\hline
\end{tabular}


Table 7: Return predictability and lead-lag effects

This table reports the weekly excess returns and alphas (in percent) of industry-neutral portfolios of stocks sorted based on predicted cumulative abnormal returns (CARs) from economically unrelated stock pairs. Quintile 1 has the lowest predicted CARs, while quintile 5 has the highest. For each quintile of stocks, we report the valueweighted excess return above the risk-free rate $(E R)$ and value-weighted alpha from a Fama-French-Carhart fourfactor regression (FFC4) in each quintile. The row labeled Q5-Q1 shows the difference between quintile 5 and quintile 1. $t$-statistics are reported in parentheses below the coefficient estimates. Panel A reports results using only stock pairs in which the target firm is from an equal or larger size decile than the economically unrelated firm (on the left) and using only stock pairs in which the target firm is from a smaller size decile than the economically unrelated firm (on the right). Panels B, C, D, E, and F report analogous results using only stock pairs in which the stocks are standalone versus conglomerates, or from different NYSE/AMEX trading volume deciles, NASDAQ trading volume deciles, institutional ownership deciles, and analyst coverage deciles, respectively.

\begin{tabular}{|c|c|c|c|c|c|c|c|}
\hline \multicolumn{8}{|c|}{ Panel A: Size of target firm versus economically unrelated firm } \\
\hline \multicolumn{4}{|c|}{ Target stock $>=$ economically unrelated stock } & \multicolumn{4}{|c|}{ Target stock < economically unrelated stock } \\
\hline Quintile & ER & FFC4 & \# Stocks & Quintile & ER & FFC4 & \# Stocks \\
\hline \multirow[t]{2}{*}{1 (Low) } & 0.018 & -0.118 & 354 & 1 (Low) & 0.095 & -0.053 & 329 \\
\hline & $(0.3)$ & $(-5.2)$ & & & $(1.5)$ & $(-3.1)$ & \\
\hline \multirow[t]{2}{*}{2} & 0.066 & -0.053 & 366 & 2 & 0.114 & -0.025 & 341 \\
\hline & $(1.2)$ & $(-2.9)$ & & & $(2.0)$ & $(-1.5)$ & \\
\hline \multirow[t]{2}{*}{3} & 0.125 & 0.011 & 366 & 3 & 0.135 & -0.009 & 341 \\
\hline & $(2.2)$ & $(0.6)$ & & & (2.3) & $(-0.6)$ & \\
\hline \multirow[t]{2}{*}{4} & 0.161 & 0.033 & 366 & 4 & 0.168 & 0.025 & 341 \\
\hline & $(2.6)$ & $(2.0)$ & & & $(2.8)$ & (1.6) & \\
\hline \multirow[t]{2}{*}{5 (High) } & 0.216 & 0.079 & 378 & 5 (High) & 0.198 & 0.046 & 353 \\
\hline & (3.1) & (3.5) & & & $(2.9)$ & $(2.7)$ & \\
\hline \multirow[t]{2}{*}{ Q5 - Q1 } & 0.198 & 0.196 & & Q5 - Q1 & 0.104 & 0.100 & \\
\hline & (5.3) & $(5.6)$ & & & $(4.4)$ & $(4.5)$ & \\
\hline \multicolumn{8}{|c|}{ Panel B: Standalone firms versus conglomerates } \\
\hline \multicolumn{4}{|c|}{ Both stocks in pair from standalone firms } & \multicolumn{4}{|c|}{ Both stocks in pair from conglomerate firms } \\
\hline Quintile & ER & FFC4 & \# Stocks & Quintile & ER & FFC4 & \# Stocks \\
\hline \multirow[t]{2}{*}{1 (Low) } & -0.010 & -0.113 & 170 & 1 (Low) & 0.018 & -0.093 & 85 \\
\hline & $(-0.2)$ & $(-3.5)$ & & & $(0.3)$ & $(-2.7)$ & \\
\hline \multirow[t]{2}{*}{2} & 0.040 & -0.045 & 181 & 2 & 0.077 & -0.014 & 97 \\
\hline & $(0.7)$ & $(-1.7)$ & & & $(1.2)$ & $(-0.5)$ & \\
\hline \multirow[t]{2}{*}{3} & 0.102 & 0.012 & 181 & 3 & 0.113 & 0.014 & 97 \\
\hline & (1.6) & $(0.4)$ & & & $(1.8)$ & $(0.5)$ & \\
\hline \multirow[t]{2}{*}{4} & 0.145 & 0.055 & 181 & 4 & 0.137 & 0.028 & 97 \\
\hline & $(2.1)$ & (1.9) & & & $(2.1)$ & (1.1) & \\
\hline \multirow[t]{2}{*}{5 (High) } & 0.202 & 0.119 & 193 & 5 (High) & 0.160 & 0.041 & 109 \\
\hline & $(2.6)$ & (3.3) & & & $(2.3)$ & (1.4) & \\
\hline \multirow[t]{2}{*}{ Q5 - Q1 } & 0.212 & 0.232 & & Q5 - Q1 & 0.142 & 0.134 & \\
\hline & $(4.0)$ & $(4.7)$ & & & $(3.1)$ & $(3.0)$ & \\
\hline
\end{tabular}




\begin{tabular}{|c|c|c|c|c|c|c|c|}
\hline \multicolumn{8}{|c|}{ Panel C: NYSE/AMEX Volume of target stock versus economically unrelated stock } \\
\hline \multicolumn{4}{|c|}{ Target stock >= economically unrelated stock } & \multicolumn{4}{|c|}{ Target stock < economically unrelated stock } \\
\hline Quintile & ER & FFC4 & \# Stocks & Quintile & ER & FFC4 & \# Stocks \\
\hline \multirow[t]{2}{*}{1 (Low) } & 0.036 & -0.104 & 198 & 1 (Low) & 0.073 & -0.071 & 177 \\
\hline & $(0.6)$ & $(-4.3)$ & & & $(1.3)$ & $(-3.3)$ & \\
\hline \multirow[t]{2}{*}{2} & 0.055 & -0.071 & 210 & 2 & 0.111 & -0.028 & 189 \\
\hline & $(1.0)$ & $(-3.4)$ & & & $(2.0)$ & $(-1.4)$ & \\
\hline \multirow[t]{2}{*}{3} & 0.100 & -0.023 & 210 & 3 & 0.132 & -0.009 & 189 \\
\hline & $(1.8)$ & $(-1.3)$ & & & $(2.4)$ & $(-0.4)$ & \\
\hline \multirow[t]{2}{*}{4} & 0.162 & 0.034 & 210 & 4 & 0.143 & 0.004 & 189 \\
\hline & $(2.8)$ & $(1.8)$ & & & $(2.5)$ & $(0.2)$ & \\
\hline \multirow[t]{2}{*}{5 (High) } & 0.201 & 0.061 & 222 & 5 (High) & 0.194 & 0.042 & 201 \\
\hline & (3.1) & $(2.8)$ & & & (3.2) & $(2.0)$ & \\
\hline \multirow[t]{2}{*}{ Q5 - Q1 } & 0.165 & 0.165 & & Q5 - Q1 & 0.122 & 0.113 & \\
\hline & $(4.7)$ & (4.9) & & & (5.4) & (5.1) & \\
\hline \multicolumn{8}{|c|}{ Panel D: Nasdaq Volume of target stock versus economically unrelated stock } \\
\hline \multicolumn{4}{|c|}{ Target stock $>=$ economically unrelated stock } & \multicolumn{4}{|c|}{ Target stock < economically unrelated stock } \\
\hline Quintile & ER & FFC4 & \# Stocks & Quintile & ER & FFC4 & \# Stocks \\
\hline \multirow[t]{2}{*}{1 (Low) } & 0.053 & -0.060 & 154 & 1 (Low) & 0.120 & -0.022 & 131 \\
\hline & $(0.6)$ & $(-1.5)$ & & & (1.7) & $(-0.8)$ & \\
\hline \multirow[t]{2}{*}{2} & 0.147 & 0.061 & 165 & 2 & 0.124 & -0.018 & 141 \\
\hline & $(1.8)$ & $(1.5)$ & & & $(2.0)$ & $(-0.8)$ & \\
\hline \multirow[t]{2}{*}{3} & 0.176 & 0.081 & 165 & 3 & 0.170 & 0.032 & 141 \\
\hline & $(2.2)$ & (1.9) & & & $(2.8)$ & (1.4) & \\
\hline \multirow[t]{2}{*}{4} & 0.284 & 0.192 & 165 & 4 & 0.194 & 0.051 & 141 \\
\hline & (3.3) & $(4.5)$ & & & $(3.0)$ & $(2.1)$ & \\
\hline \multirow[t]{2}{*}{5 (High) } & 0.208 & 0.105 & 176 & 5 (High) & 0.227 & 0.071 & 153 \\
\hline & $(2.2)$ & $(2.3)$ & & & $(3.1)$ & $(2.9)$ & \\
\hline \multirow[t]{2}{*}{ Q5 - Q1 } & 0.158 & 0.165 & & Q5 - Q1 & 0.106 & 0.093 & \\
\hline & $(2.6)$ & $(2.8)$ & & & (3.3) & $(2.9)$ & \\
\hline
\end{tabular}




\begin{tabular}{|c|c|c|c|c|c|c|c|}
\hline Panel E: I & tutiona & nership & arget sto & economi & unrel & stock & \\
\hline Target $s$ & $>=$ eco & cally un & ed stock & Target & $<$ econ & ally unr & d stock \\
\hline Quintile & ER & FFC4 & \# Stocks & Quintile & ER & FFC4 & \# Stocks \\
\hline 1 (Low) & 0.036 & -0.109 & 349 & 1 (Low) & 0.074 & -0.069 & 289 \\
\hline & $(0.6)$ & $(-4.8)$ & & & $(1.2)$ & $(-2.7)$ & \\
\hline 2 & 0.063 & -0.062 & 361 & 2 & 0.071 & -0.048 & 301 \\
\hline & $(1.1)$ & $(-3.5)$ & & & $(1.2)$ & $(-2.3)$ & \\
\hline 3 & 0.132 & 0.010 & 361 & 3 & 0.099 & -0.014 & 301 \\
\hline & (2.3) & $(0.6)$ & & & (1.8) & $(-0.6)$ & \\
\hline 4 & 0.176 & 0.046 & 361 & 4 & 0.170 & 0.040 & 301 \\
\hline & (2.9) & $(2.7)$ & & & $(2.8)$ & $(2.0)$ & \\
\hline 5 (High) & 0.202 & 0.059 & 373 & 5 (High) & 0.225 & 0.086 & 313 \\
\hline & (2.9) & $(2.7)$ & & & (3.4) & (3.6) & \\
\hline Q5 - Q1 & 0.166 & 0.169 & & Q5 - Q1 & 0.151 & 0.155 & \\
\hline & $(4.5)$ & $(4.8)$ & & & (3.9) & (4.1) & \\
\hline Panel F: A & yst cov & of tar & tock ver & $\overline{\text { mically u }}$ & $\operatorname{ated} s t$ & & \\
\hline Target $s$ & $>=$ eco & cally un & ed stock & Target & $<$ econ & ally unr & d stock \\
\hline Quintile & ER & FFC4 & \# Stocks & Quintile & ER & FFC4 & \# Stocks \\
\hline 1 (Low) & 0.026 & -0.101 & 273 & 1 (Low) & 0.045 & -0.073 & 267 \\
\hline & $(0.4)$ & $(-4.9)$ & & & $(0.8)$ & $(-3.8)$ & \\
\hline 2 & 0.047 & -0.057 & 286 & 2 & 0.082 & -0.026 & 279 \\
\hline & $(0.9)$ & $(-3.5)$ & & & (1.6) & $(-1.5)$ & \\
\hline 3 & 0.111 & 0.006 & 285 & 3 & 0.126 & 0.012 & 279 \\
\hline & $(2.1)$ & $(0.4)$ & & & $(2.4)$ & $(0.7)$ & \\
\hline 4 & 0.141 & 0.029 & 286 & 4 & 0.145 & 0.022 & 279 \\
\hline & (2.5) & (1.9) & & & $(2.6)$ & (1.3) & \\
\hline 5 (High) & 0.206 & 0.073 & 297 & 5 (High) & 0.169 & 0.032 & 291 \\
\hline & (3.3) & (3.8) & & & $(2.8)$ & (1.9) & \\
\hline Q5 - Q1 & 0.181 & 0.174 & & Q5 - Q1 & 0.125 & 0.105 & \\
\hline & (5.5) & (5.6) & & & (4.4) & (3.9) & \\
\hline
\end{tabular}


Table 8: Return predictability and characteristic-based explanations

This table reports the weekly excess return in percent for portfolios based on double sorts of predicted cumulative abnormal returns (CARs) and other characteristics. For each characteristic, we form 25 portfolios by independent industry-neutral sorts on predicted CAR and the firm characteristic. The portfolios are formed and rebalanced weekly. We report value-weighted excess returns above risk-free rate for each of the 25 portfolios. The row labeled Q5-Q1 shows the difference in estimate for quintile 5 minus quintile 1, with the $t$-statistic in parentheses below the difference. Earnings surprise is measured by three-day abnormal returns for the earnings announcement within the past 60 days of portfolio formation. Market capitalization, book-to-market ratio, and past returns are as of the month prior to portfolio formation.

\begin{tabular}{|c|c|c|c|c|c|}
\hline \multirow{2}{*}{$\begin{array}{r}\text { Pred. CAR } \\
\text { Quintile }\end{array}$} & \multicolumn{5}{|c|}{ Market Capitalization (Size) Quintile } \\
\hline & 1 (Small) & 2 & 3 & 4 & $5(\mathrm{Big})$ \\
\hline 1 (Low) & 0.130 & 0.106 & 0.097 & 0.096 & 0.017 \\
\hline 5 (High) & 0.286 & 0.264 & 0.192 & 0.179 & 0.227 \\
\hline \multirow[t]{2}{*}{ Q5 - Q1 } & 0.155 & 0.158 & 0.091 & 0.079 & 0.211 \\
\hline & (4.6) & (4.7) & (2.9) & (2.3) & (4.8) \\
\hline
\end{tabular}

\begin{tabular}{cccccc}
\hline Pred. CAR & \multicolumn{5}{c}{ Book-to-Market (Growth vs Value) Quintile } \\
\cline { 2 - 6 } Quintile & 1 (Growth) & 2 & 3 & 4 & 5 (Value) \\
\hline 1 (Low) & 0.018 & 0.015 & 0.051 & -0.027 & 0.147 \\
5 (High) & 0.208 & 0.191 & 0.251 & 0.196 & 0.318 \\
\hline Q5 - Q1 & 0.189 & 0.174 & 0.203 & 0.228 & 0.172 \\
& $(3.5)$ & $(3.3)$ & $(4.0)$ & $(3.8)$ & $(3.4)$ \\
\hline
\end{tabular}

\begin{tabular}{cccccc}
\hline Pred. CAR & \multicolumn{5}{c}{ Past 1-wk Return (Weekly Reversal) Quintile } \\
\cline { 2 - 6 } Quintile & 1 (Loser) & 2 & 3 & 4 & 5 (Winner) \\
\hline 1 (Low) & 0.393 & 0.140 & 0.037 & -0.090 & -0.251 \\
5 (High) & 0.664 & 0.353 & 0.198 & 0.129 & -0.099 \\
\hline Q5 - Q1 & 0.269 & 0.213 & 0.154 & 0.224 & 0.153 \\
& $(4.4)$ & $(4.0)$ & $(2.9)$ & $(4.2)$ & $(2.7)$ \\
\hline
\end{tabular}

\begin{tabular}{rccccc}
\hline Pred. CAR & \multicolumn{5}{c}{ Past 1-mo Return (Monthly Reversal) Quintile } \\
\cline { 2 - 6 } Quintile & 1 (Loser) & 2 & 3 & 4 & 5 (Winner) \\
\hline 1 (Low) & 0.080 & 0.104 & 0.075 & -0.026 & -0.032 \\
5 (High) & 0.195 & 0.286 & 0.209 & 0.208 & 0.218 \\
\hline Q5 - Q1 & 0.113 & 0.174 & 0.139 & 0.234 & 0.251 \\
& $(1.8)$ & $(3.1)$ & $(2.5)$ & $(4.4)$ & $(4.8)$ \\
\hline
\end{tabular}

\begin{tabular}{cccccc}
\hline Pred. CAR & \multicolumn{5}{c}{ Past 12-2 month (Momentum) Return Quintile } \\
\cline { 2 - 6 } Quintile & 1 (Loser) & 2 & 3 & 4 & 5 (Winner) \\
\hline 1 (Low) & -0.034 & 0.060 & 0.050 & 0.023 & 0.131 \\
5 (High) & 0.058 & 0.143 & 0.185 & 0.198 & 0.301 \\
\hline Q5 - Q1 & 0.089 & 0.082 & 0.139 & 0.175 & 0.169 \\
& $(1.4)$ & $(1.4)$ & $(2.6)$ & $(3.4)$ & $(3.4)$ \\
\hline
\end{tabular}




\begin{tabular}{|c|c|c|c|c|c|}
\hline \multirow{2}{*}{$\begin{array}{r}\text { Pred. CAR } \\
\text { Quintile }\end{array}$} & \multicolumn{5}{|c|}{ Past 60-13 month (Long Run Reversal) Return Quintile } \\
\hline & 1 (Loser) & 2 & 3 & 4 & 5 (Winner) \\
\hline 1 (Low) & 0.143 & 0.068 & -0.014 & -0.040 & 0.025 \\
\hline 5 (High) & 0.223 & 0.246 & 0.274 & 0.252 & 0.193 \\
\hline \multirow[t]{2}{*}{ Q5 - Q1 } & 0.084 & 0.174 & 0.281 & 0.293 & 0.170 \\
\hline & $(1.4)$ & $(3.2)$ & $(5.0)$ & $(5.0)$ & $(2.8)$ \\
\hline \multirow{2}{*}{$\begin{array}{c}\text { Pred. CAR } \\
\text { Quintile } \\
\end{array}$} & \multicolumn{5}{|c|}{ Earnings Surprise (Earnings Momentum) Quintile } \\
\hline & $1(\mathrm{Bad})$ & 2 & 3 & 4 & 5 (Good) \\
\hline 1 (Low) & 0.036 & -0.014 & -0.006 & 0.093 & 0.127 \\
\hline 5 (High) & 0.151 & 0.137 & 0.289 & 0.223 & 0.242 \\
\hline \multirow[t]{2}{*}{ Q5 - Q1 } & 0.118 & 0.155 & 0.292 & 0.131 & 0.116 \\
\hline & $(1.9)$ & $(2.7)$ & $(5.2)$ & $(2.5)$ & $(2.2)$ \\
\hline \multirow{2}{*}{$\begin{array}{c}\text { Pred. CAR } \\
\text { Quintile } \\
\end{array}$} & \multicolumn{5}{|c|}{ Amihud Illiquidity Quintile } \\
\hline & 1 (Low) & 2 & 3 & 4 & 5 (High) \\
\hline 1 (Low) & 0.024 & 0.052 & 0.109 & 0.078 & 0.080 \\
\hline 5 (High) & 0.224 & 0.174 & 0.192 & 0.266 & 0.281 \\
\hline \multirow[t]{2}{*}{ Q5 - Q1 } & 0.198 & 0.124 & 0.079 & 0.181 & 0.205 \\
\hline & $(4.3)$ & $(3.3)$ & $(2.3)$ & $(5.4)$ & $(5.4)$ \\
\hline \multirow{2}{*}{$\begin{array}{r}\text { Pred. CAR } \\
\text { Quintile }\end{array}$} & \multicolumn{5}{|c|}{ NYSE/AMEX Trading Volume Quintile } \\
\hline & 1 (Low) & 2 & 3 & 4 & 5 (High) \\
\hline 1 (Low) & 0.103 & 0.051 & 0.080 & 0.050 & 0.016 \\
\hline 5 (High) & 0.258 & 0.202 & 0.222 & 0.221 & 0.206 \\
\hline \multirow[t]{2}{*}{ Q5 - Q1 } & 0.144 & 0.145 & 0.139 & 0.177 & 0.184 \\
\hline & $(3.2)$ & $(4.0)$ & $(3.7)$ & $(4.3)$ & $(4.0)$ \\
\hline \multirow{2}{*}{$\begin{array}{r}\text { Pred. CAR } \\
\text { Quintile } \\
\end{array}$} & \multicolumn{5}{|c|}{ NYSE/AMEX Turnover Quintile } \\
\hline & 1 (Low) & 2 & 3 & 4 & 5 (High) \\
\hline 1 (Low) & 0.002 & -0.033 & 0.023 & 0.066 & 0.059 \\
\hline 5 (High) & 0.220 & 0.248 & 0.225 & 0.142 & 0.236 \\
\hline \multirow[t]{2}{*}{ Q5 - Q1 } & 0.206 & 0.290 & 0.196 & 0.074 & 0.173 \\
\hline & (3.2) & $(5.0)$ & (3.9) & (1.4) & (3.0) \\
\hline
\end{tabular}


Table 9: Fama-MacBeth regressions of return predictability with controls

This table reports results from Fama-MacBeth regressions of stocks' realized excess returns in week $\mathrm{t}+1$ on sets of explanatory variables. The predicted cumulative abnormal return (Predicted CAR) is the stock's quintile rank calculated based on all pairs of economically unrelated stocks in columns (1) and (2), based on pairs of economically unrelated stocks with significant common institutional owners in columns (3) and (4), and based on pairs of economically unrelated stocks without significant common institutional owners in columns (5) and (6). Return week $t-1$, Return month $t$ - 1 , and Return month $t$-60 to $t$-13 control for weekly, monthly, and long-term return reversals. Return month $t-12$ to $t-2$ and Earnings surprise control for price momentum and earnings momentum. The remaining explanatory variables control for other stock characteristics known to be related to return predictability. All explanatory variables are defined in Appendix A. $t$-statistics (in parentheses) are based on Newey-West standard errors.

\begin{tabular}{|c|c|c|c|c|c|c|}
\hline & $(1)$ & $(2)$ & (3) & $(4)$ & $(5)$ & $(6)$ \\
\hline Predicted CAR: all pairs & $\begin{array}{c}0.0003 \\
(8.2)\end{array}$ & $\begin{array}{c}0.0003 \\
(10.7)\end{array}$ & & & & \\
\hline $\begin{array}{l}\text { Predicted CAR: pairs with significant } \\
\text { common institutional owners }\end{array}$ & & & $\begin{array}{c}0.0004 \\
(7.1)\end{array}$ & $\begin{array}{l}0.0003 \\
(8.4)\end{array}$ & & \\
\hline $\begin{array}{l}\text { Predicted CAR: pairs without significant } \\
\text { common institutional owners }\end{array}$ & & & & & $\begin{array}{l}0.0000 \\
(0.1)\end{array}$ & $\begin{array}{c}-0.0031 \\
(-1.0)\end{array}$ \\
\hline Return week t-1 & & $\begin{array}{l}-0.0671 \\
(-29.6)\end{array}$ & & $\begin{array}{l}-0.0587 \\
(-23.0)\end{array}$ & & $\begin{array}{l}-0.0636 \\
(-22.7)\end{array}$ \\
\hline Return month t-1 & & $\begin{array}{c}-0.0039 \\
(-4.0)\end{array}$ & & $\begin{array}{c}-0.0013 \\
(-1.1)\end{array}$ & & $\begin{array}{c}-0.0026 \\
(-2.1)\end{array}$ \\
\hline Return month t- 60 to $\mathrm{t}-13$ & & $\begin{array}{c}-0.0002 \\
(-2.7)\end{array}$ & & $\begin{array}{c}-0.0001 \\
(-2.2)\end{array}$ & & $\begin{array}{c}-0.0001 \\
(-0.8)\end{array}$ \\
\hline Return month $\mathrm{t}-12$ to $\mathrm{t}-2$ & & $\begin{array}{c}0.0010 \\
(2.5)\end{array}$ & & $\begin{array}{c}0.0007 \\
(1.5)\end{array}$ & & $\begin{array}{l}0.0013 \\
(2.9)\end{array}$ \\
\hline Earnings surprise & & $\begin{array}{c}0.0001 \\
(5.3)\end{array}$ & & $\begin{array}{l}0.0001 \\
(3.0)\end{array}$ & & $\begin{array}{l}0.0001 \\
(3.6)\end{array}$ \\
\hline Market capitalization & & $\begin{array}{c}0.0000 \\
(-3.1)\end{array}$ & & $\begin{array}{l}0.0000 \\
(0.2)\end{array}$ & & $\begin{array}{l}0.0000 \\
(0.6)\end{array}$ \\
\hline Book-to-market equity & & $\begin{array}{c}0.0001 \\
(0.3)\end{array}$ & & $\begin{array}{c}0.0000 \\
(-0.1)\end{array}$ & & $\begin{array}{c}0.0000 \\
(0.0)\end{array}$ \\
\hline Operating accruals & & $\begin{array}{c}-0.0022 \\
(-3.2)\end{array}$ & & $\begin{array}{c}-0.0026 \\
(-3.1)\end{array}$ & & $\begin{array}{c}-0.0055 \\
(-3.8)\end{array}$ \\
\hline Net stock issuance & & $\begin{array}{c}-0.0031 \\
(-5.5)\end{array}$ & & $\begin{array}{c}-0.0028 \\
(-4.9)\end{array}$ & & $\begin{array}{c}-0.0015 \\
(-1.4)\end{array}$ \\
\hline Idiosyncratic volatility & & $\begin{array}{l}0.0044 \\
(0.2)\end{array}$ & & $\begin{array}{l}0.0090 \\
(0.4)\end{array}$ & & $\begin{array}{l}0.0114 \\
(0.5)\end{array}$ \\
\hline Amihud illiquidity & & $\begin{array}{c}0.0001 \\
(1.9)\end{array}$ & & $\begin{array}{c}0.0000 \\
(0.0)\end{array}$ & & $\begin{array}{c}0.0000 \\
(0.4)\end{array}$ \\
\hline Intercept & $\begin{array}{c}0.0010 \\
(1.7)\end{array}$ & $\begin{array}{c}0.0008 \\
(1.6)\end{array}$ & $\begin{array}{c}0.0007 \\
(1.0)\end{array}$ & $\begin{array}{c}0.0003 \\
(0.6)\end{array}$ & $\begin{array}{c}0.0020 \\
(1.9)\end{array}$ & $\begin{array}{c}0.0250 \\
(1.2)\end{array}$ \\
\hline Average \# of stocks per week & 1838 & 1288 & 1743 & 1245 & 1361 & 1064 \\
\hline Average adjusted $\mathrm{R}^{2}$ & 0.001 & 0.045 & 0.001 & 0.044 & 0.001 & 0.045 \\
\hline
\end{tabular}




\section{Table 10: Return predictability from positive versus negative predicted-return pairs}

This table reports the weekly excess returns and alphas (in percent) of industry-neutral portfolios of stocks sorted based on predicted cumulative abnormal returns (CARs) from economically unrelated stock pairs that have significant common institutional owners for the period 1980-2010. Quintile 1 has the lowest predicted CARs, while quintile 5 has the highest. For each quintile of stocks, we report the value-weighted excess return above the risk-free rate (ER), and the value-weighted alpha from CAPM (CAPM), Fama-French three-factor (FF3), and Fama-FrenchCarhart four-factor (FFC4) regressions. The row labeled Q5-Q1 shows the difference between quintile 5 and quintile 1. $t$-statistics are reported in parentheses below the coefficient estimates. Panel A reports predictability results using only stock pairs for which the predicted return is negative (Pairs Predicting Negative Returns ) versus only stock pairs predicting positive returns ( Pairs Predicting Positive Returns), and the difference. Panel B reports the predictability results using only stock pairs predicting negative returns, further dividing them into negative predictions arising from the Unrelated-Stock-Loss channel (positive historical correlation with negative recent return on the unrelated stock) and from the Return-Chasing channel (negative historical correlation with positive recent return on the unrelated stock).

\begin{tabular}{|c|c|c|c|c|c|c|c|c|c|c|c|c|}
\hline \multirow[b]{3}{*}{ Quintile } & \multirow{2}{*}{\multicolumn{4}{|c|}{ Pairs Predicting Negative Returns }} & \multirow{2}{*}{\multicolumn{4}{|c|}{ Pairs Predicting Positive Returns }} & \multirow{2}{*}{\multicolumn{4}{|c|}{ Negative - Positive Difference }} \\
\hline & & & & & & & & & & & & \\
\hline & ER & CAPM & FF3 & FFC4 & ER & CAPM & FF3 & FFC4 & ER & CAPM & FF3 & FFC4 \\
\hline \multirow[t]{2}{*}{1 (Low) } & 0.111 & -0.066 & -0.081 & -0.070 & 0.101 & -0.021 & -0.018 & -0.019 & 0.010 & -0.045 & -0.063 & -0.051 \\
\hline & $(1.2)$ & $(-1.7)$ & $(-2.6)$ & $(-2.3)$ & $(1.7)$ & $(-1.2)$ & $(-1.1)$ & $(-1.2)$ & $(0.2)$ & $(-0.9)$ & $(-1.6)$ & $(-1.3)$ \\
\hline \multirow[t]{2}{*}{2} & 0.133 & -0.023 & -0.038 & -0.033 & 0.149 & 0.010 & 0.009 & 0.004 & -0.016 & -0.033 & -0.046 & -0.036 \\
\hline & $(1.7)$ & $(-0.8)$ & $(-1.5)$ & $(-1.3)$ & $(2.2)$ & $(0.6)$ & $(0.5)$ & $(0.2)$ & $(-0.5)$ & $(-1.0)$ & $(-1.6)$ & $(-1.2)$ \\
\hline \multirow[t]{2}{*}{3} & 0.114 & -0.037 & -0.045 & -0.042 & 0.155 & 0.004 & -0.006 & 0.001 & -0.041 & -0.041 & -0.039 & -0.043 \\
\hline & $(1.6)$ & $(-1.7)$ & $(-2.2)$ & $(-2.1)$ & $(2.1)$ & $(0.2)$ & $(-0.3)$ & $(0.0)$ & $(-1.8)$ & $(-1.8)$ & $(-1.7)$ & $(-1.9)$ \\
\hline \multirow[t]{2}{*}{4} & 0.103 & -0.038 & -0.041 & -0.042 & 0.173 & 0.014 & 0.010 & 0.013 & -0.071 & -0.052 & -0.051 & -0.055 \\
\hline & (1.5) & $(-2.2)$ & $(-2.4)$ & $(-2.4)$ & $(2.2)$ & $(0.5)$ & $(0.4)$ & $(0.5)$ & $(-2.1)$ & $(-1.6)$ & $(-1.7)$ & $(-1.9)$ \\
\hline \multirow[t]{2}{*}{5 (High) } & 0.140 & 0.013 & 0.019 & 0.016 & 0.165 & -0.015 & -0.025 & -0.014 & -0.025 & 0.028 & 0.044 & 0.030 \\
\hline & $(2.3)$ & $(0.8)$ & $(1.3)$ & $(1.1)$ & $(1.8)$ & $(-0.4)$ & $(-0.7)$ & $(-0.4)$ & $(-0.5)$ & $(0.6)$ & $(1.1)$ & $(0.7)$ \\
\hline \multirow[t]{2}{*}{ Q5 - Q1 } & 0.029 & 0.080 & 0.100 & 0.086 & 0.065 & 0.006 & -0.006 & 0.006 & -0.036 & 0.073 & 0.107 & 0.081 \\
\hline & $(0.5)$ & (1.7) & (2.6) & (2.3) & (1.1) & $(0.1)$ & $(-0.2)$ & $(0.1)$ & $(-0.3)$ & $(0.8)$ & (1.4) & (1.1) \\
\hline
\end{tabular}

\begin{tabular}{|c|c|c|c|c|c|c|c|c|c|c|c|c|}
\hline anel B: & based & ock pai & redicti & nly nes & $\operatorname{comp}$ & of of "U & lated-s & k-Loss & -Chasin & channel & & \\
\hline & $\begin{array}{r}\text { Pairs } \mathrm{F} \\
\text { "L }\end{array}$ & $\begin{array}{l}\text { cting N } \\
\text { ated-St }\end{array}$ & $\begin{array}{l}\text { ive Ret } \\
\text { Loss" c }\end{array}$ & $\begin{array}{l}\text { due to } \\
\text { nel }\end{array}$ & Pairs $\mathrm{P}$ & $\begin{array}{l}\text { cting } \mathrm{Ne} \\
\text { turn-Ch }\end{array}$ & $\begin{array}{l}\text { ive Ret } \\
\text { g" char }\end{array}$ & due to & "Unrela & $\begin{array}{r}\text { Stock-L } \\
\text { Dif }\end{array}$ & $\begin{array}{l}\text { - "Retu } \\
\text { nce }\end{array}$ & Chasing" \\
\hline Quintile & ER & CAPM & FF3 & FFC4 & ER & CAPM & FF3 & FFC4 & ER & CAPM & FF3 & FFC4 \\
\hline 1 (Low) & 0.108 & -0.063 & -0.084 & -0.074 & 0.142 & -0.031 & -0.047 & -0.037 & -0.034 & -0.032 & -0.038 & -0.037 \\
\hline & $(1.2)$ & $(-1.7)$ & $(-2.8)$ & $(-2.5)$ & (1.6) & $(-0.9)$ & $(-1.5)$ & $(-1.2)$ & $(-1.3)$ & $(-1.2)$ & $(-1.4)$ & $(-1.4)$ \\
\hline 2 & 0.088 & -0.068 & -0.085 & -0.080 & 0.124 & -0.033 & -0.050 & -0.041 & -0.036 & -0.035 & -0.035 & -0.039 \\
\hline & $(1.1)$ & $(-2.4)$ & $(-3.3)$ & $(-3.1)$ & (1.6) & $(-1.1)$ & $(-1.9)$ & $(-1.5)$ & $(-1.4)$ & $(-1.4)$ & $(-1.4)$ & $(-1.6)$ \\
\hline 3 & 0.136 & -0.011 & -0.018 & -0.015 & 0.112 & -0.035 & -0.043 & -0.044 & 0.024 & 0.025 & 0.025 & 0.029 \\
\hline & (1.9) & $(-0.5)$ & $(-0.9)$ & $(-0.8)$ & (1.6) & $(-1.7)$ & $(-2.2)$ & $(-2.2)$ & (1.1) & (1.1) & (1.1) & (1.3) \\
\hline 4 & 0.107 & -0.032 & -0.033 & -0.034 & 0.100 & -0.040 & -0.040 & -0.040 & 0.006 & 0.008 & 0.007 & 0.006 \\
\hline & (1.6) & $(-2.0)$ & $(-2.1)$ & $(-2.1)$ & (1.5) & $(-2.4)$ & $(-2.4)$ & $(-2.3)$ & $(0.4)$ & $(0.5)$ & $(0.4)$ & $(0.3)$ \\
\hline 5 (High) & 0.143 & 0.015 & 0.022 & 0.018 & 0.146 & 0.020 & 0.026 & 0.022 & -0.003 & -0.005 & -0.004 & -0.004 \\
\hline & (2.3) & $(0.9)$ & (1.5) & (1.2) & (2.4) & (1.2) & (1.7) & (1.5) & $(-0.3)$ & $(-0.6)$ & $(-0.5)$ & $(-0.4)$ \\
\hline Q5 - Q1 & 0.036 & 0.078 & 0.106 & 0.092 & 0.004 & 0.051 & 0.072 & 0.059 & 0.031 & 0.027 & 0.033 & 0.033 \\
\hline & $(0.7)$ & (1.7) & $(2.8)$ & (2.5) & $(0.1)$ & (1.1) & $(2.0)$ & (1.6) & (1.1) & $(0.9)$ & $(1.2)$ & (1.2) \\
\hline
\end{tabular}




\section{Table 11: Stock pairs without correlated earnings surprises}

We estimate each stock's quarterly unexpected earnings (earnings surprise) using a seasonal random walk model with drift (Chan et al., 1996; Sadka, 2006) and then calculate time-series correlations of unexpected earnings using all available observations. To reduce estimation error, we require at least 12 observations to estimate correlations. Panel A presents descriptive statistics for the time-series correlations of earnings surprises for the economically unrelated stock pairs used in the main analysis. Panel B reports the weekly excess returns and alphas (in percent) of industry-neutral portfolios of stocks sorted based on predicted cumulative abnormal returns (CARs) from economically unrelated stock pairs, excluding stock pairs whose time-series correlations are significant at the 5\% level (approximately $9.5 \%$ of the stock pairs). Quintile 1 has the lowest predicted CARs, while quintile 5 has the highest. For each quintile of stocks, we report the value-weighted excess return above the risk-free rate (ER) and the value-weighted alphas from CAPM (CAPM), the Fama-French three-factor model (FF3), and the Fama-French-Carhart four-factor model (FFC4). The average number of stocks in each portfolio is reported under \# Stocks. The row labeled Q5-Q1 shows the difference between quintile 5 and quintile 1.t-statistics are reported in parentheses below the coefficient estimates.

\begin{tabular}{lrrrr}
\hline \multicolumn{5}{l}{ Panel A: Distribution of time-series correlations of earnings surprises for economically unrelated stock pairs } \\
\hline & Mean & $25^{\text {th }}$ P'tile $^{\prime}$ & Median & $75^{\text {th }}$ P'tile $^{\prime}$ \\
\hline Correlation & 0.017 & -0.144 & 0.012 & 0.177 \\
t-statistic & 0.10 & -0.65 & 0.05 & 0.80 \\
p-value & 0.48 & 0.20 & 0.48 & 0.75 \\
\hline
\end{tabular}

\begin{tabular}{cccccc}
\hline \multicolumn{6}{c}{ Panel B: Return predictability excluding stock pairs with correlat } \\
\hline Quintile & ER & CAPM & FF3 & FFC4 & \# Stocks \\
\hline 1 (Low) & 0.020 & -0.106 & -0.130 & -0.119 & 356 \\
& $(0.3)$ & $(-4.4)$ & $(-5.7)$ & $(-5.3)$ & \\
2 & 0.070 & -0.047 & -0.049 & -0.045 & 368 \\
& $(1.2)$ & $(-2.6)$ & $(-2.8)$ & $(-2.6)$ & \\
3 & 0.108 & -0.010 & -0.009 & -0.007 & 368 \\
& $(1.9)$ & $(-0.6)$ & $(-0.5)$ & $(-0.4)$ & \\
4 & 0.175 & 0.047 & 0.050 & 0.046 & 368 \\
& $(2.9)$ & $(2.8)$ & $(3.0)$ & $(2.8)$ & \\
5 (High) & 0.207 & 0.067 & 0.074 & 0.071 & 380 \\
& $(3.0)$ & $(3.0)$ & $(3.3)$ & $(3.2)$ & \\
\hline Q5 - Q1 & 0.188 & 0.172 & 0.204 & 0.191 & \\
& $(5.0)$ & $(4.7)$ & $(5.8)$ & $(5.4)$ & \\
\hline
\end{tabular}


Figure 2: Long-short portfolio returns by week, with versus without significant common institutional investors

This figure shows the Fama-French-Carhart four-factor alpha from the strategy of going long the quintile portfolio with the highest predicted CAR (Quintile 5) and short the quintile portfolio with the lowest predicted CAR (Quintile 1), holding the portfolio from one week to 12 weeks after portfolio formation, where predicted returns are based on either stock pairs with significant common institutional owners (With Significant Common Inst'l Owners) or stock pairs without significant common institutional owners (No Significant Common Inst'l Owners).

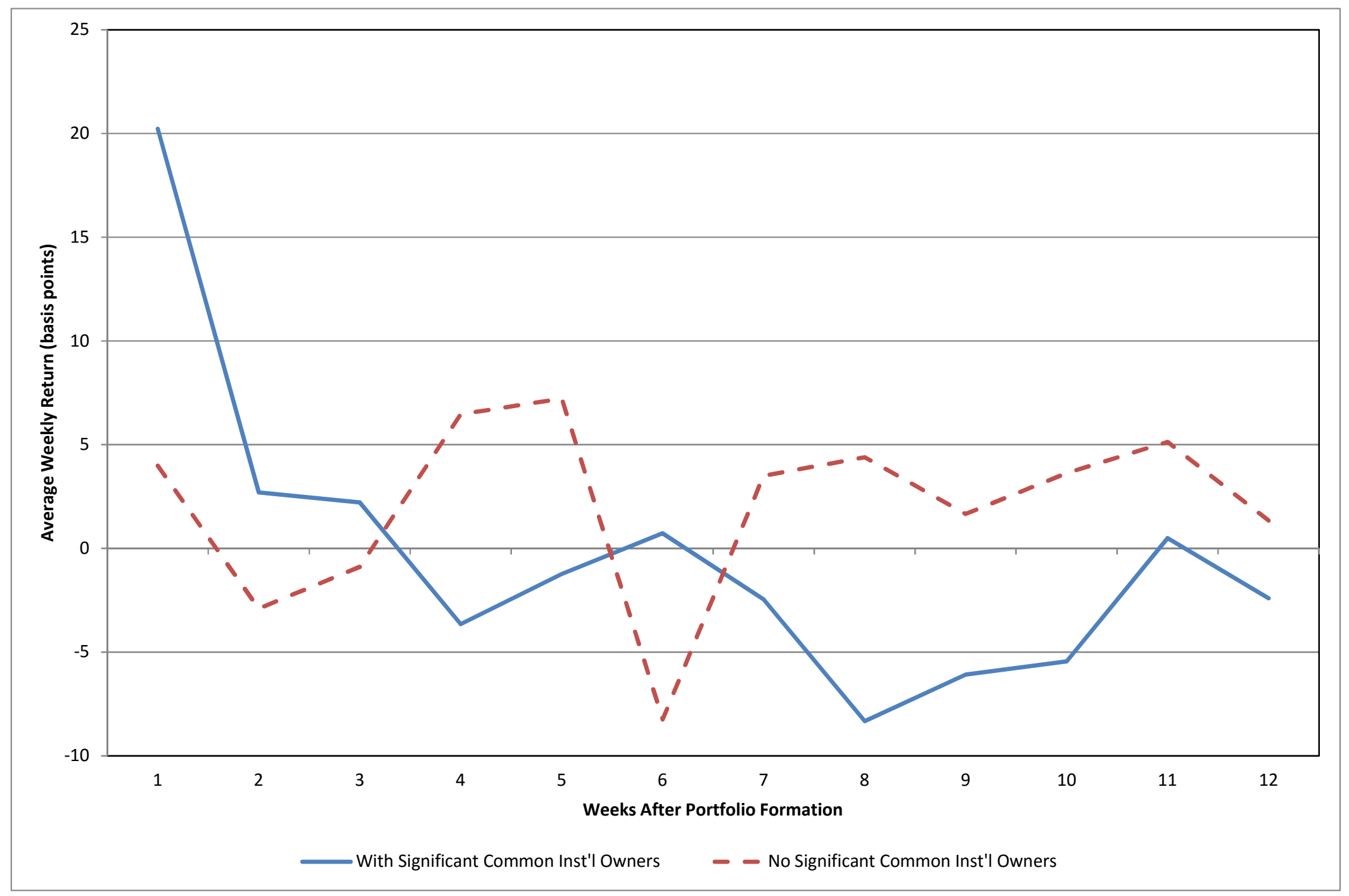




\section{Figure 3: Annual long-short portfolio returns and Sharpe ratios}

This figure shows the annual excess return and Sharpe ratio each year from the strategy of going long the quintile portfolio with the highest predicted CAR (Quintile 5) and short the quintile portfolio with the lowest predicted CAR (Quintile 1). The long-short hedge portfolio annual return is calculated as the average weekly return multiplied by the number of weeks in the year. The annual Sharpe ratio is calculated as the annual return divided by the annual standard deviation of returns, which equals the standard deviation of weekly returns multiplied by the square root of the number of weeks in the year.

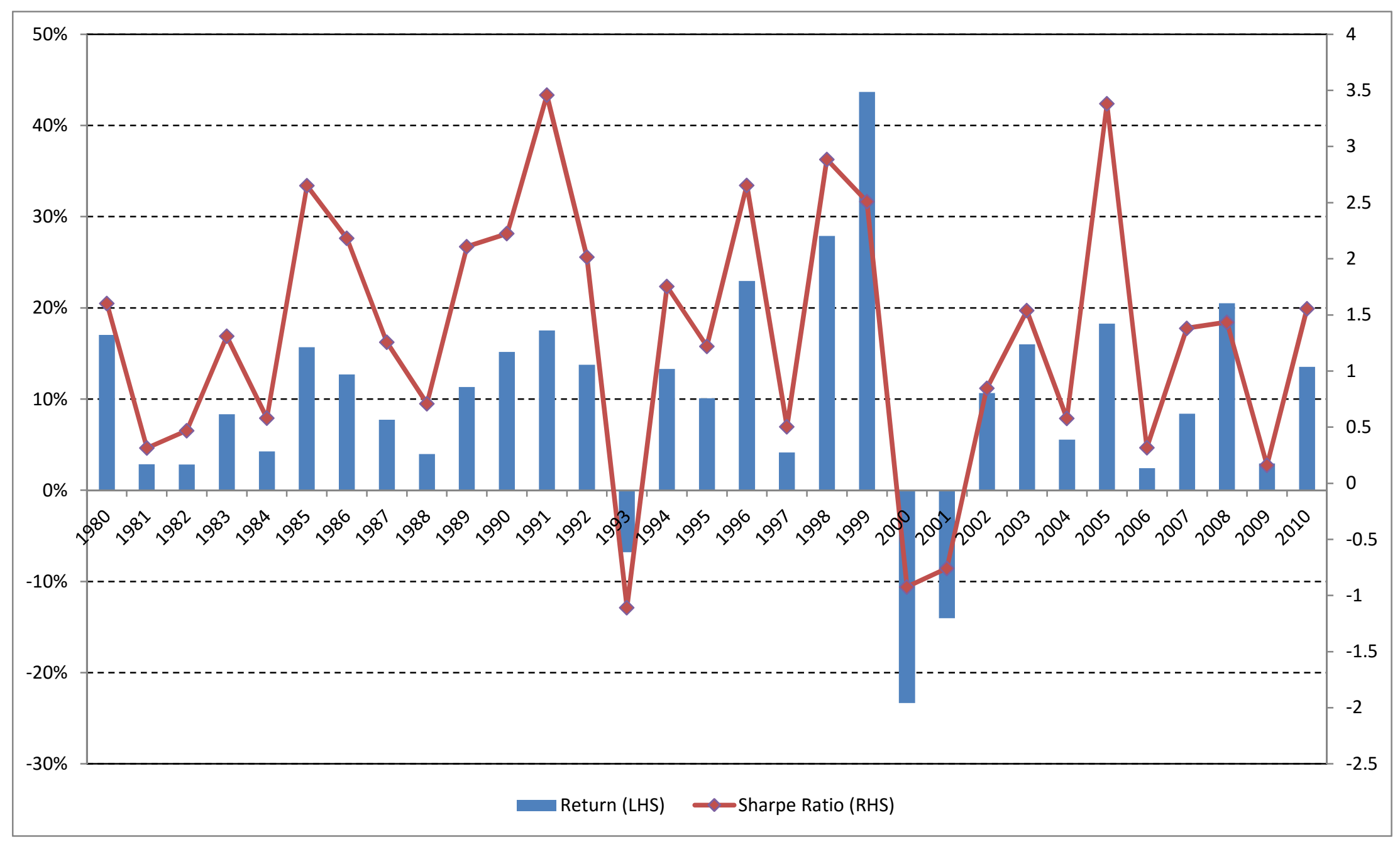

